\title{
HAVE A BREAK, HAVE A ... NATIONAL CURRENCY: WHEN DO MONETARY UNIONS FALL APART?
}

\author{
VOLKER NITSCH
}

\section{CESIFO WORKING PAPER NO. 1113}

CATEGORY 6: MONETARY POLICY AND INTERNATIONAL FINANCE

JANUARY 2004

Presented at Venice Summer Institute, Workshop on Monetary Unions after EMU, JULY 2003

\footnotetext{
An electronic version of the paper may be downloaded

- from the SSRN website:

- from the CESifo website:

www.SSRN.com

www. CESifo.de
} 


\title{
HaVe a Break, Have A ... NATIONAL CURRENCY: WHEN DO MONETARY UNIONS FALL APART?
}

\begin{abstract}
Historically, dissolutions of currency unions are not unusual. I use an annual panel data set covering 245 country pairs that use a common currency (of which 128 are dissolved) from 1948 through 1997 to characterize currency union exits. I find that departures from a currency union tend to occur when there is a large inflation differential between member countries, when the currency union involves a country which is closed to international trade and trade flows dry up, and when there is a change in the political status of a member. In general, however, macroeconomic factors have only little predictive power for currency union dissolutions.
\end{abstract}

JEL Classification: F31, F33, F36.

Keywords: monetary union, sovereign currency, dissolution, exit.

\author{
Volker Nitsch \\ Free University Berlin \\ Department of Economics \\ Boltzmannstrasse 20 \\ 14195 Berlin \\ Germany \\ vnitsch@wiwiss.fu-berlin.de
}

I thank Graziella Bertocchi, Benjamin Cohen, Charles Goodhart, Jacques Mélitz, Barbara Pistoresi, Andrew Rose, Kiril Strahilov, an anonymous referee and participants at the CEPR conference on "Macroeconomics and Economic Geography", the CESifo Venice Summer Institute workshop on "Monetary Unions after EMU", the 2002 meeting of the European Trade Study Group, the 2003 meeting of the Verein fuer Socialpolitik and the Humboldt University Macro seminar for helpful comments. 


\section{$\underline{\text { I. Introduction }}$}

In recent years, monetary integration has become fashionable again. Twelve European countries have formed a monetary union, giving up their national currencies for the euro. Other countries have dollarized, adopting the currency of another country on a unilateral basis. After some decades in which almost all countries, except for some small and geographically remote territories, strongly preferred to have their own monies, more than twothirds of the sovereign countries in the world are either considering to abandon their national money or already have done so. ${ }^{1}$

One of the main reasons for the countries' growing willingness to enter a currency union is the credibility of these arrangements. In contrast to other hard currency pegs (such as fixed exchange rates or currency boards), the abandonment of a country's own currency is often assumed to be permanent; it cannot be easily reversed and, thus, appears to be a more serious commitment than any other fixed-rate regime. For Europeans, the use of a common currency implies a degree of integration that goes much beyond the elimination of exchange rate volatility. For dollarized countries, the adoption of another country's currency means that monetary policy is delegated directly to a foreign authority.

Historically, however, dissolutions of currency unions are not unusual. Reuven Glick and Andrew Rose (2002) even find that for the period from 1948 through 1997 currency union exits clearly outnumber currency union entries. Of the 146 regime transitions (for which they have data), there were 130 switches out of but only 16 switches into currency unions.

In this paper, I examine why some monetary unions fall apart, while others remain in existence for a long period of time. In particular, I ask when does a country leave a currency union. By comparing the behavior of countries in currency unions shortly before their dissolution with that of sustained currency unions, I am able to identify potential causes of

\footnotetext{
${ }^{1}$ Alberto Alesina and Robert Barro (2001, p. 381) note that "roughly 60 small countries or territories [of the 193 independent countries] have for some time been members of currency unions or have used a large country's money", including the 15-member CFA franc zone in Africa and the 7-member Eastern Caribbean Currency Area. In terms of GDP, however, this group of countries (excluding anchor countries) makes up less than 1 percent of world GDP. If one adds to this list the 12-member European Monetary Union, the accession countries in Europe, the countries in West Africa, Southern Africa and the Arab Gulf region that have declared their intention to form a currency union as well as the Latin American countries that seriously consider dollarization, the number of countries without a national currency is easily doubled and the combined GDP is increased by several orders of magnitude.
} 
currency union break-ups. ${ }^{2}$ My empirical results suggest that departures from a currency union tend to occur when there is a large inflation differential between member countries, when the currency union involves a country which is relatively closed to international trade and trade flows fall, and when there is a change in political status of a member. In general, however, macroeconomic factors have only little predictive power for currency union dissolutions.

This paper adds to an already large and again rapidly growing literature on currency unions. Most of the recent (empirical) studies, however, explore the degree of integration in currency unions relative to countries with different national monies. Rose and Charles Engel (2002), for instance, measure several economic characteristics for currency union members and compare them to non-currency union countries. Alesina, Barro and Silvana Tenreyro (2002) rank country pairs by their degree of integration and attempt to identify optimal currency areas. Here, however, I focus exclusively on existing currency unions which then may or may not have been sustained; countries with separate currencies are ignored.

This paper is also related (and close in style) to the rich empirical literature on the determinants of changes in exchange rate regimes. Turbulences in foreign exchange markets (like regime transitions and currency crashes) have attracted much attention, and numerous studies attempt to link these episodes to macroeconomic and political variables. Examples include Barry Eichengreen, Rose and Charles Wyplosz (1995), Jeffrey Frankel and Rose (1996), and Graciela Kaminsky and Carmen Reinhart (1999); Kaminsky, Saul Lizondo and Reinhart (1998) provide a survey. To my knowledge, however, there is no study that focuses on the break-ups of currency unions.

The remainder of the paper is as follows. The next section provides some analytical background. I then describe the data and their characteristics, followed by a presentation of the results of multivariate analyses. After presenting some more illustrative details, the paper ends with a brief summary.

\section{$\underline{\text { II. Background }}$}

In order to determine factors that may help to explain why countries leave a currency union, the large theoretical literature on fixed exchange rates offers at least two different analytical frameworks. The first is based on Robert Mundell's (1961) concept of an “optimum currency area". This concept emphasizes the costs and benefits of monetary integration and

\footnotetext{
${ }^{2}$ In future work, I intend to explore the (short-term) macroeconomic effects of currency union dissolutions.
} 
argues that the (net) gains from sharing a single currency increase with the degree of economic integration. The dissolution of a currency union can then be viewed as evidence that the members were not part of an optimum currency area; the benefits of using the same money (e.g., lower transaction costs in trading goods and services) were (ex post) smaller than the costs (e.g., the loss of an independent monetary policy). In empirical work, typically four criteria (or a subset) are examined to identify an optimum currency area: the intensity of trade, the symmetry of shocks and cycles, the degree of labor mobility, and the mechanism of fiscal transfers. For dissolved currency unions then, I would expect to find, based on these criteria, a lower degree of integration than for sustained unions.

The alternative framework is provided by the literature on currency crises and speculative attacks. The idea here is that a country may be forced to leave a currency union even if the currency union members generally exhibit the desirable degree of economic integration. Of course, the credibility of the commitment to use the same money makes members of a currency union less vulnerable (and maybe even immune) to a speculative attack. However, similar to other fixed exchange rate arrangements, inconsistencies between domestic economic fundamentals and the exchange rate commitment may arise. Poor policies, for instance, can rapidly increase the costs of monetary integration so that, at some point, a country may decide that it is no longer willing to bear these costs; Roberto Chang and Andrés Velasco (2002) provide a recent formalization of this time inconsistency problem. To identify empirically when a currency link becomes unsustainable, the literature on currency crises has used a large variety of indicators; Kaminsky et al.'s (1998) summary of 28 selected studies lists alone 105 indicators. ${ }^{3}$ It follows that also a much broader set of macroeconomic and financial variables may be relevant in explaining currency union break-ups.

A third (intuitively plausible) view is that currency union dissolutions are mainly the result of changes in the political status of a territory; many departures from a currency union link indeed occurred when a colony gained independence and subsequently left the currency area of the former colonizer. ${ }^{4}$ Most recently, the break-up of federations in Eastern Europe (the Soviet Union, Yugoslavia, Czechoslovakia) has illustrated the importance of political ties for monetary integration; the dissolution of the political union was also accompanied by a

\footnotetext{
${ }^{3}$ Kaminsky et al. (1998, p. 2) conclude: "The results indicate that an effective warning system [of currency crises] should consider a broad variety of indicators, since currency crises seem to usually be preceded by a broad range of economic problems."

${ }^{4}$ William Bomberger (2002) argues that the decline in trade after currency union dissolution is mainly the result of a reorientation of trade flows after former colonies gained independence rather than reflecting the change in the currency union status.
} 
dissolution of the monetary union. ${ }^{5}$ This view then implies that currency union exits are largely unrelated to economic fundamentals.

In the empirical analysis, I try to account for these different explanations. Based on the literature on optimum currency areas, I examine the intensity of the ties between currency union members. In particular, I enter explanatory variables not only in absolute levels or rates of change (reflecting the economic conditions in a country) but also relative to the same variable in a partner country using the same currency; this allows to identify the effect of asymmetries and differentials on the likelihood of currency union break-up. Similar to other empirical studies on transitions in the exchange rate regime, I also explore the impact of a wide range of potential indicators. The list of variables can be broadly grouped into five categories and also includes a measure of change in the political status; the remaining groups are: 1) macroeconomic indicators; 2) financial variables; 3) fiscal measures; and 4) openness variables. The next section describes the data set in more detail.

\section{$\underline{\text { III. Data }}$}

The data used in this paper come essentially from two sources. Most of the data are obtained from Glick and Rose (2002); they have compiled a data set of macroeconomic variables for 217 countries and territories, covering the period from 1948 through 1997 on an annual basis. This data set has, for my purposes, several useful features. First, it is extremely comprehensive; the data set covers most of the post-war period and virtually all political entities in the world (i.e., countries, territories, colonies, dependencies and so on). Assembled in pairwise form, it comprises more than 400,000 observations although there are many observations missing. ${ }^{6}$ Second, the data are extracted from standard sources such as the World Bank's World Development Indicators or the IMF's International Financial Statistics; they have been checked and corrected for mistakes. Finally, and most notably, the data set contains information on whether a pair of countries shares the same currency. Based on this currency union dummy, I construct a binary variable for a break-up of the currency union in the following year that will serve as regressand in my analysis (as a robustness check, I also construct a dummy variable for currency union break-up in one of the following three years). More details are discussed in Glick and Rose (2002).

\footnotetext{
${ }^{5}$ As Charles Goodhart (1995, p. 449) puts it: "Political, not economic, events have caused the monetary changes in Central and Eastern Europe; economic considerations, although important, have been secondary."

${ }^{6}$ For instance, Glick and Rose's sample includes only observations for country pairs with positive bilateral trade.
} 
Figure 1: Description of the Data

a) Number of (Currency Union) Observations

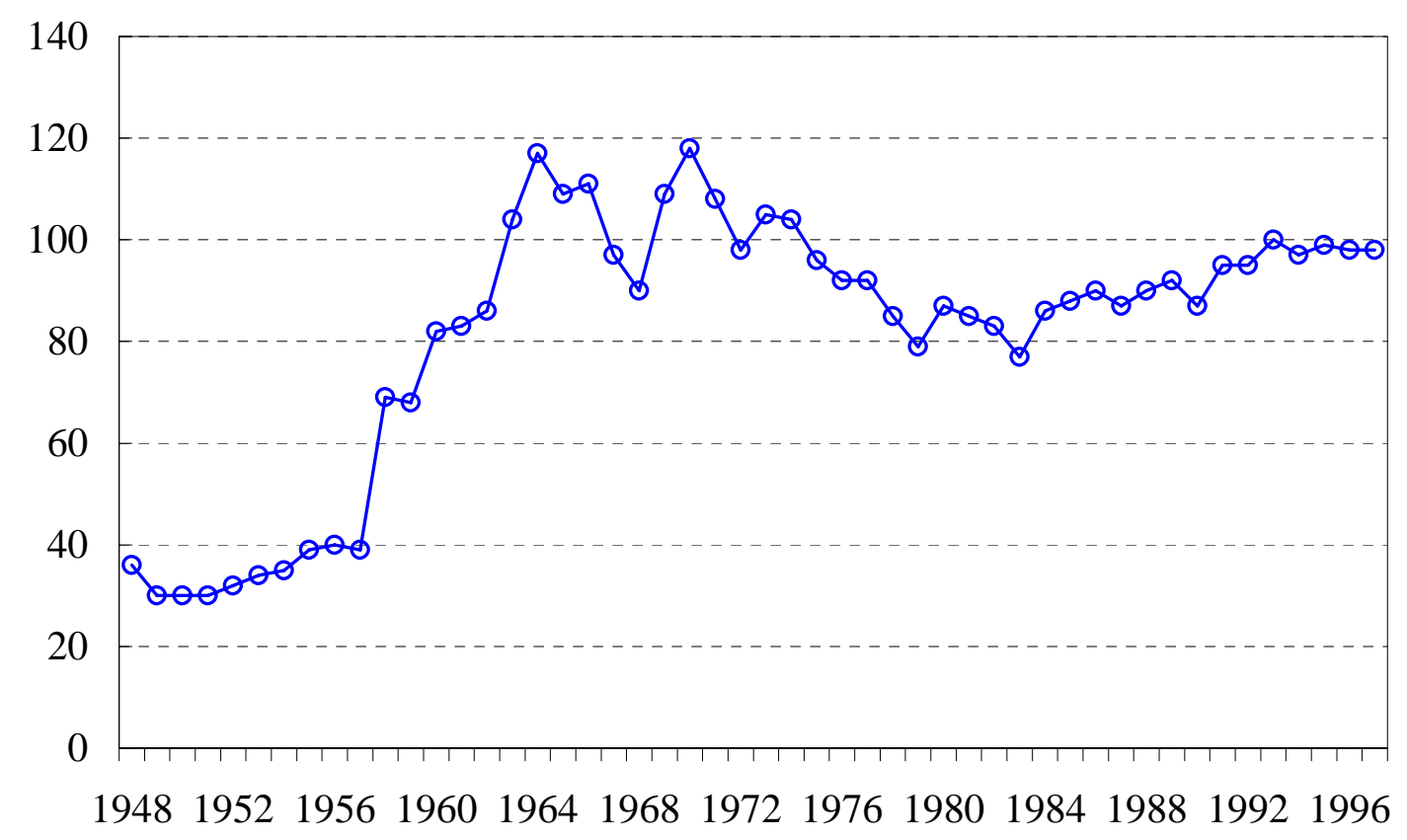

b) Number of Currency Union Dissolutions

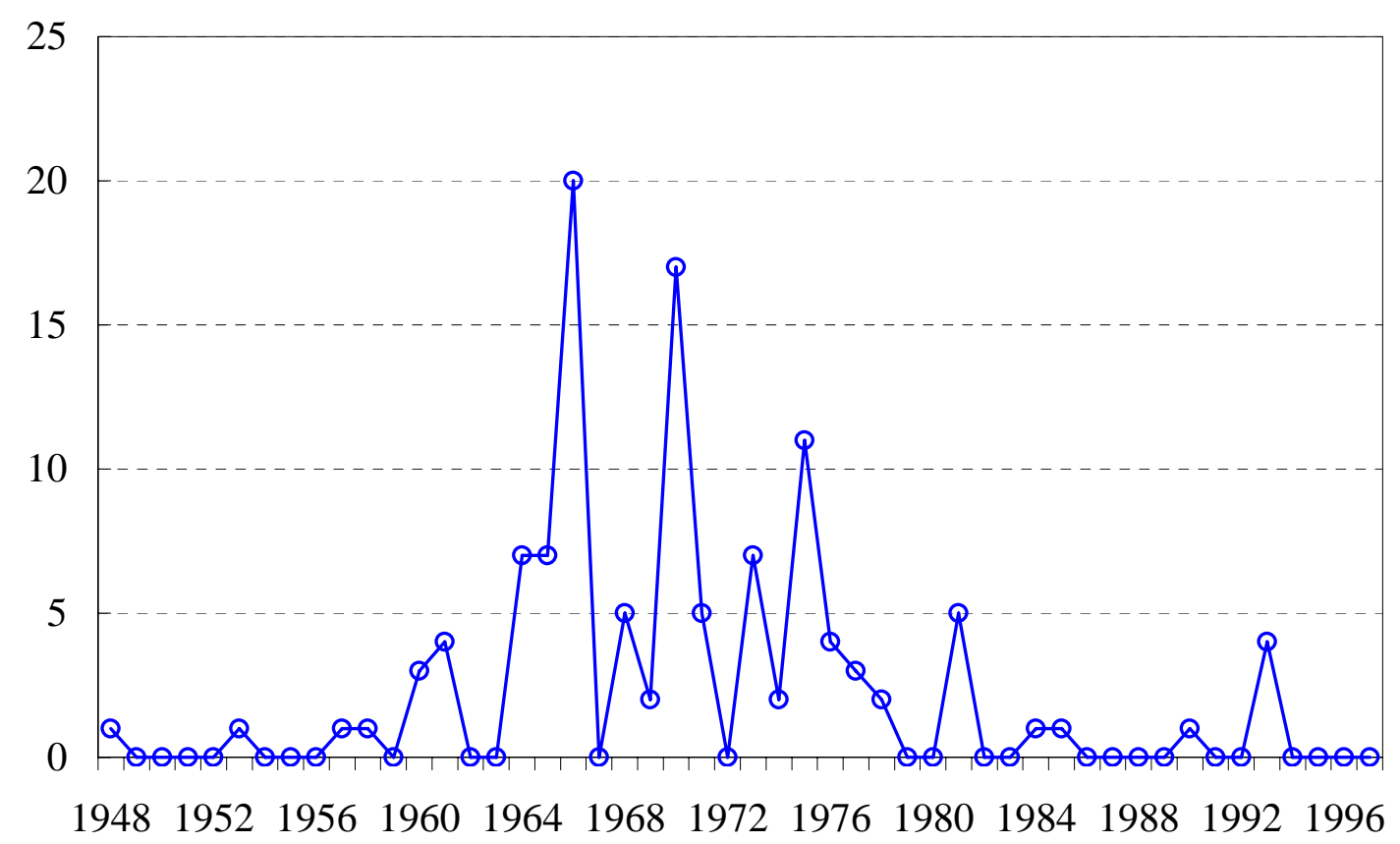


In the actual implementation, I extract a subset from this large panel data set, containing the observations of currency union pairs. This leaves 4,625 observations for 245 currency unions (or, more precisely, country pairs in a currency union) of which 128 are dissolved during the sample period; the currency unions and the exits are tabulated in the appendix. Figure 1 displays the distribution of observations over time. While the number of observations has a slight tendency to increase over time (mostly due to a better availability of data), currency union exits most often occured in the 1960s and $1970 \mathrm{~s}^{7}$; some of these currency union dissolutions are related so that the observations probably should not be treated as independent observations.

To this data set, I add a number of other macroeconomic and financial variables, taken from Rose and Engel (2002). This data set covers a broad set of indicators typically employed in empirical studies on currency crises. Rose and Engel have used these variables to characterize currency unions, I utilize them to characterize currency union exits. In particular, I apply all of their macroeconomic, financial, fiscal and openness variables. ${ }^{8}$ The exact list of variables is in table 1 which also shows some descriptive statistics.

\section{Results}

\subsection{Univariate Evidence}

In table 1, I report separate means and standard deviations for sustained currency unions (defined to exist for at least the next three years) and dissolved currency union links ${ }^{9}$; this allows to compare (in univariate fashion) the average behavior of the variable of interest for broken and non-broken currency unions. I also include a $p$-value for a $t$-test of equality of means; differences in means that are statistically significant at the 5 percent level are in bold.

\footnotetext{
${ }^{7}$ None of the results changes when the analysis is confined to this period.

${ }^{8}$ I ignore their measures of educational attainment and geographic remoteness.

${ }^{9}$ For broken currency union links, I tabulate the results for the period up to three years prior the break and the (one) year immediately preceding the break. The motivation is that an exit from a currency union (i.e., the introduction and circulation of a country's own new national money) may require some time for preparations (e.g., the establishment of a central bank, the design and printing of banknotes). Therefore, economic conditions a few years before a currency union dissolution may be more relevant in explaining this event than the situation shortly before the break. As shown in the table, however, there are only minor differences in the results.
} 
Table 1: Descriptive Statistics

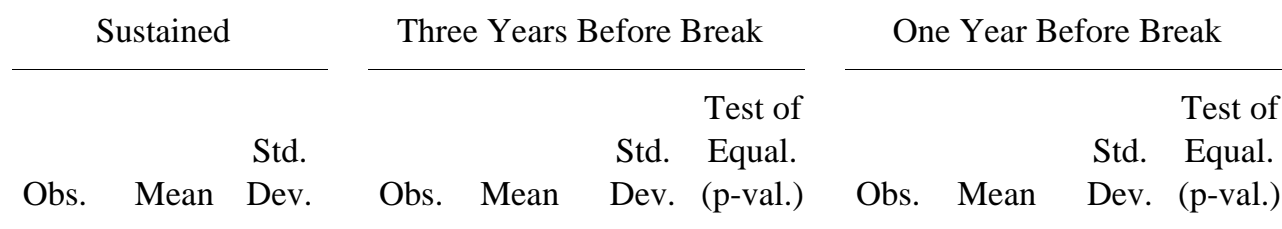

A. Macroeconomic Variables

Real GDP Growth (\%)

minimum, pair-wise

difference, pair-wise

Real GDP per Capita (\$)

minimum, pair-wise

difference, pair-wise

$\begin{array}{rrr}2603 & 0.5 & 8.2 \\ 2603 & 7.4 & 10.6\end{array}$

237

$\begin{array}{lll}0.3 & 5.8 & 0.77\end{array}$

$\begin{array}{llll}237 & 8.8 & 14.2 & 0.05\end{array}$

$\begin{array}{llll}83 & -1.3 & 6.5 & 0.05\end{array}$

$\begin{array}{llll}83 & 8.4 & 6.5 & 0.36\end{array}$

Private Consumption Growth (\%)

$\begin{array}{lll}1036 & 1818 & 2710\end{array}$

$\begin{array}{llll}20 & 1554 & 764 & 0.66\end{array}$

$\begin{array}{llll}10 & 1359 & 689 & 0.59\end{array}$

$\begin{array}{lllllll}1036 & 1495 & 2568 & \mathbf{2 0} & \mathbf{4 3 8 6} & \mathbf{6 1 7 1} & \mathbf{0 . 0 0}\end{array}$

$\begin{array}{llll}10 & 3243 & 5807 & 0.04\end{array}$

minimum, pair-wise

difference, pair-wise

Total Consumption Growth (\%)

minimum, pair-wise

difference, pair-wise

Inflation $(\%)$

maximum, pair-wise

difference, pair-wise

$\begin{array}{lll}1603 & -1.8 & 8.5\end{array}$

$\begin{array}{lll}1603 & 10.3 \quad 10.9\end{array}$

$\begin{array}{llll}115 & -1.3 & 7.0 & 0.47\end{array}$

$\begin{array}{llll}115 & 10.0 & 8.8 & 0.78\end{array}$

$\begin{array}{lll}1510 & -1.3 & 7.1\end{array}$

$\begin{array}{lll}1510 & 8.9 & 9.0\end{array}$

$\begin{array}{llll}64 & -1.1 & 7.0 & 0.82\end{array}$

$\begin{array}{llll}64 & 10.2 & 7.6 & 0.24\end{array}$

$\begin{array}{lll}1419 & 9.1 & 8.2\end{array}$

$129 \quad 12.3$

$14.7 \quad 0.00$

$1419 \quad 4.5 \quad 4.5$

$\begin{array}{llll}129 & 7.1 & 13.5 & 0.00\end{array}$ $\begin{array}{llll}45 & -2.0 & 6.8 & 0.93\end{array}$

$\begin{array}{llll}45 & 13.8 & 10.5 & 0.04\end{array}$

$\begin{array}{llll}25 & -2.5 & 7.6 & 0.40\end{array}$

$\begin{array}{llll}25 & 13.7 & 8.5 & 0.01\end{array}$

$\begin{array}{llll}45 & 16.6 & 22.1 & 0.00\end{array}$

$\begin{array}{llll}45 & 11.0 & 21.2 & 0.00\end{array}$

B. Financial Variables

\section{M2/GDP (\%)}

maximum, pair-wise

difference, pair-wise

M2/GDP Growth (\%)

minimum, pair-wise

difference, pair-wise

Interest Rate Spread (\%)

maximum, pair-wise

difference, pair-wise

Credit to Private Sector (\%GDP)

maximum, pair-wise

difference, pair-wise

1558

$\begin{array}{lll}1558 & 8.8 \quad 8.3\end{array}$

$\begin{array}{lll}1398 & -2.8 & 8.2\end{array}$

$\begin{array}{lll}1398 & 9.7 & 9.0\end{array}$

$\begin{array}{lll}956 & 5.0 & 4.4\end{array}$

$\begin{array}{lll}956 & 1.3 \quad 1.5\end{array}$

$\begin{array}{lll}1586 & 31.9 & 18.2\end{array}$

$\begin{array}{lll}1586 & 12.4 & 12.9\end{array}$

Credit to Priv. Sector Growth (\%)

minimum, pair-wise

difference, pair-wise

1425

1425

Domestic Banking Credit (\%GDP)

maximum, pair-wise

difference, pair-wise

$\begin{array}{lll}1584 & 37.9 & 23.0\end{array}$

$\begin{array}{lll}1584 & 15.2 & 22.0\end{array}$

Dom. Banking Credit Growth (\%)

minimum, pair-wise

difference, pair-wise

$1423 \quad-5.3 \quad 13.1$

$\begin{array}{lll}1423 & 17.7 & 19.2\end{array}$ $\begin{array}{llll}51 & 31.7 & 16.7 & 0.80\end{array}$

$\begin{array}{llll}51 & 12.1 & 13.2 & 0.01\end{array}$

$\begin{array}{llll}41 & -3.7 & 9.4 & 0.49\end{array}$

$\begin{array}{llll}41 & 8.8 & 9.6 & 0.54\end{array}$

$\begin{array}{llll}12 & 5.1 & 4.6 & 0.99\end{array}$

$\begin{array}{llll}12 & 3.4 & 3.0 & 0.00\end{array}$

$\begin{array}{llll}60 & 37.7 & 23.2 & 0.02\end{array}$

$\begin{array}{llll}60 & 19.5 & 18.5 & 0.00\end{array}$

$\begin{array}{llll}45 & -2.9 & 12.0 & 0.11\end{array}$

$\begin{array}{llll}45 & 26.1 & 94.0 & 0.00\end{array}$

$\begin{array}{llll}60 & 45.8 & 27.2 & 0.01\end{array}$

$\begin{array}{llll}60 & 20.5 & 22.2 & 0.07\end{array}$

$\begin{array}{llll}45 & -3.1 & 16.6 & 0.27\end{array}$

$\begin{array}{llll}45 & 29.1 & 75.0 & 0.00\end{array}$ $\begin{array}{llll}22 & 33.4 & 16.4 & 0.51\end{array}$

$\begin{array}{llll}22 & 12.8 & 12.8 & 0.03\end{array}$

$\begin{array}{llll}13 & -3.7 & 14.4 & 0.71\end{array}$

$\begin{array}{llll}13 & 13.8 & 14.4 & 0.10\end{array}$

$\begin{array}{llll}5 & 4.8 & 4.3 & 0.91\end{array}$

$\begin{array}{llll}5 & 3.3 & 2.2 & 0.00\end{array}$

$\begin{array}{llll}28 & 37.7 & 23.2 & 0.09\end{array}$

$\begin{array}{llll}28 & 20.6 & 18.6 & 0.00\end{array}$

$\begin{array}{llll}15 & -5.7 & 14.8 & 0.89\end{array}$

$\begin{array}{llll}15 & 59.7 & 160 & 0.00\end{array}$

$\begin{array}{llll}28 & 47.2 & 26.7 & 0.04\end{array}$

$\begin{array}{llll}28 & 23.1 & 22.9 & 0.06\end{array}$

$\begin{array}{llll}15 & -6.2 & 24.2 & 0.77\end{array}$

$\begin{array}{llll}15 & 54.0 & 128 & 0.00\end{array}$

C. Fiscal Variables

Current Revenue (\%GDP)

maximum, pair-wise

difference, pair-wise

$\begin{array}{lll}302 & 23.7 & 6.9\end{array}$

$\begin{array}{lll}302 & 7.6 & 5.8\end{array}$

22

$\begin{array}{lll}22.7 & 6.5 & 0.53\end{array}$

$\begin{array}{llll}22 & 6.7 & 5.5 & 0.47\end{array}$

$5 \quad 23.0$

$6.7 \quad 0.83$

Tax Revenue (\%GDP)

maximum, pair-wise

difference, pair-wise

$\begin{array}{lllllll}353 & 20.1 & 4.7 & 25 & 20.0 & 5.0 & 0.88\end{array}$

56

$\begin{array}{ll}5.2 & 0.59\end{array}$

Trade Taxes (\%Revenues)

$\begin{array}{lllllll}353 & 5.5 & 4.3 & 25 & 6.0 & 3.7 & 0.60\end{array}$

$\begin{array}{llll}6 & 20.2 & 5.3 & 0.97\end{array}$

maximum, pair-wise

difference, pair-wise

$\begin{array}{lll}340 & 38.8 & 12.8\end{array}$

$\begin{array}{llll}34 & 34.2 & 14.0 & 0.05\end{array}$

$\begin{array}{llll}6 & 5.9 & 3.7 & 0.84\end{array}$

$340 \quad 17.9 \quad 15.2$

$\begin{array}{llll}34 & 22.3 & 13.8 & 0.11\end{array}$

$10 \quad 34.0$

$15.3 \quad 0.25$

$\begin{array}{llll}10 & 25.1 & 13.3 & 0.14\end{array}$ 
Table 1 continued

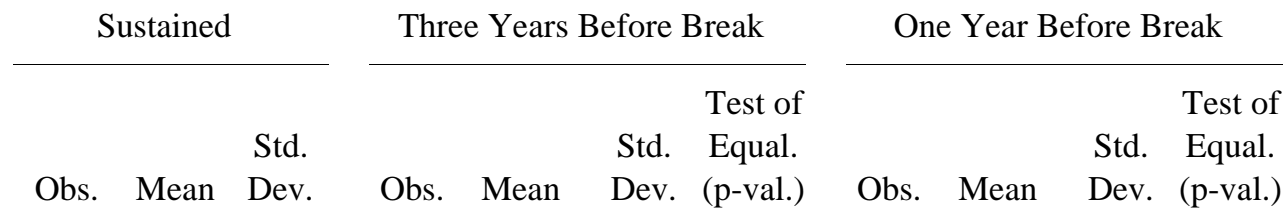

\begin{tabular}{|c|c|c|c|c|c|c|c|c|c|c|c|}
\hline \multicolumn{12}{|c|}{ C. Fiscal Variables (continued) } \\
\hline \multicolumn{12}{|l|}{ Expenditures (\%GDP) } \\
\hline maximum, pair-wise & 313 & 30.0 & 8.9 & 18 & 30.9 & 8.6 & 0.68 & 6 & 32.5 & 11.4 & 0.50 \\
\hline difference, pair-wise & 313 & 10.0 & 8.3 & 18 & 10.6 & 5.6 & 0.78 & 6 & 12.9 & 6.7 & 0.2 \\
\hline \multicolumn{12}{|l|}{ Budget Deficit (\%GDP) } \\
\hline maximum, pair-wise & 286 & -0.8 & 2.3 & 18 & -2.1 & 2.5 & 0.03 & 6 & -1.2 & 2.6 & \\
\hline difference, pair-wise & 286 & 4.9 & 5.5 & 18 & 2.7 & 1.7 & 0.09 & 6 & 3.6 & 1.4 & \\
\hline \multicolumn{12}{|c|}{ Central Government Debt (\%GDP) } \\
\hline maximum, pair-wise & 61 & 47.8 & 34.2 & 7 & 23.4 & 15.9 & 0.07 & 3 & 29.9 & 8.5 & \\
\hline difference, pair-wise & 61 & 20.7 & 25.4 & 7 & 8.9 & 6.4 & 0.23 & 3 & 14.1 & 5.4 & \\
\hline
\end{tabular}

\section{Openness Variables}

Current Account (\%GDP) minimum, pair-wise difference, pair-wise

Exports/GDP (\%) maximum, pair-wise difference, pair-wise

\begin{tabular}{|c|c|c|c|c|c|c|c|c|c|c|c|}
\hline minimum, pair-wise & 1188 & -11.4 & 9.6 & 36 & -9.0 & 5.2 & 0.14 & 15 & -7.6 & 5.2 & 0.13 \\
\hline $\begin{array}{l}\text { difference, pair-wise } \\
\text { xports/GDP }(\%)\end{array}$ & 1188 & 7.9 & 9.2 & 36 & 5.2 & 3.8 & 0.08 & 15 & 5.3 & 4.2 & 0.27 \\
\hline maximum, pair-wise & 1971 & 39.1 & 16.3 & 151 & 36.5 & 19.4 & 0.05 & 58 & 34.7 & 17.7 & 0.04 \\
\hline $\begin{array}{l}\text { difference, pair-wise } \\
\text { xport Growth }(\%)\end{array}$ & 1971 & 16.9 & 13.7 & 151 & 18.3 & 14.8 & 0.22 & 58 & 16.9 & 14.0 & 0.99 \\
\hline minimum, pair-wise & 1442 & -3.5 & 12.2 & 63 & -4.8 & 13.7 & 0.42 & 25 & -11.6 & 14.0 & 0.00 \\
\hline $\begin{array}{l}\text { difference, pair-wise } \\
\text { xxport Duties (\%Exports) }\end{array}$ & 1442 & 17.5 & 17.4 & 63 & 21.4 & 23.7 & 0.09 & 25 & 27.8 & 26.4 & 0.00 \\
\hline maximum, pair-wise & 280 & 4.3 & 3.2 & 19 & 15.7 & 14.4 & 0.00 & 4 & 23.5 & 12.4 & 0.00 \\
\hline $\begin{array}{l}\text { difference, pair-wise } \\
\text { mports/GDP }(\%)\end{array}$ & 280 & 2.6 & 2.9 & 19 & 13.1 & 13.5 & 0.00 & 4 & 18.6 & 11.0 & 0.00 \\
\hline maximum, pair-wise & 1971 & 46.0 & 20.3 & 151 & 39.4 & 20.5 & 0.00 & 58 & 38.0 & 19.0 & 0.00 \\
\hline $\begin{array}{l}\text { difference, pair-wise } \\
\text { mport Growth }(\%)\end{array}$ & 1971 & 16.0 & 16.2 & 151 & 17.2 & 16.0 & 0.39 & 58 & 16.6 & 14.9 & 0.78 \\
\hline minimum, pair-wise & 1442 & -4.0 & 11.4 & 63 & -7.1 & 15.0 & 0.03 & 25 & -15.6 & 17.7 & 0.00 \\
\hline $\begin{array}{l}\text { difference, pair-wise } \\
\text { mport Duties (\%Imports) }\end{array}$ & 1442 & 16.0 & 15.6 & 63 & 26.3 & 24.8 & $\mathbf{0 . 0 0}$ & 25 & 31.4 & 20.6 & 0.00 \\
\hline maximum, pair-wise & 326 & 22.2 & 7.0 & 30 & 15.1 & 6.5 & 0.00 & 8 & 11.7 & 6.3 & 0.00 \\
\hline $\begin{array}{l}\text { difference, pair-wise } \\
\text { rade/GDP (\%) }\end{array}$ & 326 & 8.5 & 6.9 & 30 & 6.1 & 4.9 & 0.07 & 8 & 6.9 & 6.9 & 0.52 \\
\hline maximum, pair-wise & 1011 & 38.7 & 44.6 & 20 & 26.0 & 18.3 & 0.21 & 10 & 21.8 & 7.7 & 0.23 \\
\hline $\begin{array}{l}\text { difference, pair-wise } \\
\text { Jross FDI (\%GDP) }\end{array}$ & 1011 & 21.7 & 41.0 & 20 & 13.2 & 17.7 & 0.36 & 10 & 9.2 & 7.3 & 0.34 \\
\hline aximum, pair-wise & 859 & 2.0 & 3.0 & 20 & 1.0 & 0.7 & 0.14 & 10 & 0.7 & 0.5 & 0.18 \\
\hline difference, pair-wise & 859 & 1.4 & 2.4 & 20 & 0.9 & 0.6 & 0.37 & 10 & 0.6 & 0.4 & 0.30 \\
\hline vate Capital Fl & DP) & & & & & & & & & & \\
\hline ximum, pair-wise & 865 & 17.4 & 43.6 & 20 & 10.0 & 5.2 & 0.44 & 10 & 8.4 & 3.9 & 0.51 \\
\hline ference, pair-wise & 865 & 12.5 & 43.1 & 20 & 4.2 & 4.0 & 0.39 & 10 & 4.2 & 4.0 & 0.54 \\
\hline teral Trade Growth (\%) & 3393 & 1.2 & 26.3 & 289 & -0.7 & 12.3 & 0.22 & 102 & -1.2 & 18.5 & 0.37 \\
\hline
\end{tabular}

Export Growth (\%) minimum, pair-wise difference, pair-wise

Export Duties (\%Exports) maximum, pair-wise difference, pair-wise Imports/GDP (\%) maximum, pair-wise difference, pair-wise

Import Growth (\%) minimum, pair-wise difference, pair-wise Import Duties (\%Imports) maximum, pair-wise difference, pair-wise

Trade/GDP (\%) maximum, pair-wise difference, pair-wise

Gross FDI (\%GDP)

E. Institutional Variable

Change in Political Union

$\begin{array}{llllllllllll}\text { Dummy } & 3531 & 0.01 & 0.12 & \mathbf{3 0 1} & \mathbf{0 . 0 5} & \mathbf{0 . 2 2} & \mathbf{0 . 0 0} & \mathbf{1 0 5} & \mathbf{0 . 0 5} & \mathbf{0 . 2 1} & \mathbf{0 . 0 0}\end{array}$

Notes: "Sustained" currency unions are defined to exist for at least the following three years. The p-values refer to a comparison of means between broken and sustained unions; differences significant at the $5 \%$ level are in bold. 
I begin with macroeconomic variables. The first two lines of table 1 display the results for real GDP growth. They show that the minimum growth rate ${ }^{10}$ for each country pair averages about 0.5 percent for a typical (sustained) currency union, is on average only slightly below this level ( 0.3 percent) in the three years before a currency union dissolution, but falls to -1.3 percent in the year immediately preceding the break. The results also indicate that a currency union exit is often preceded by a (negative) idiosyncratic shock to one of the members. Broken currency unions display a considerably larger difference in pair-wise growth rates than sustained currency unions (although the deviation just misses statistical significance at the 5 percent level). This is consistent with the literature on optimum currency areas where countries whose business cycles are imperfectly synchronized with others' benefit the most from the potential stabilization of a national monetary policy.

The results for other macroeconomic variables confirm this finding. Broken currency unions are characterized by a particularly large difference in the members' GDP per capita; this differential is a crude indication of a large asymmetry in shocks and cycles, but may also support the hypothesis that many currency union exits followed decolonization. Also consumption growth varies widely in dissolved currency unions shortly before the break.

The most convincing piece of evidence, however, is the economically and statistically large difference in the behavior of inflation between sustained and broken currency unions. Country pairs in dissolved currency unions tend to have a much higher rate of inflation and display also a much larger difference in inflation rates than country pairs in sustained currency unions. Moreover, the deviation from a typical currency union pair seems to accelerate during the run-up to the currency union break. The average (maximum) rate of inflation increases from 12.3 percent in the three years before a break to 16.6 percent immediately before the break (compared with 9.1 percent in tranquil, non-break periods); the inflation differential rises from 7.1 to 11 percentage points (compared with 4.5 percentage points in periods of tranquillity).

Next, I consider financial variables; these variables often feature prominently in studies of banking and exchange rate crises (see, for instance, Kaminsky and Reinhart [1999]). Most of the measures show statistically significant differences across financial systems in dissolved currency unions relative to sustained ones. For instance, the ratio of M2 to GDP, a measure of financial depth, varies by about 12 percentage points in the run-up to a regime switch compared with an average of less than 9 percentage points in sustained

\footnotetext{
${ }^{10}$ The minimum growth rate is the lower value in GDP growth for each country pair/year observation.
} 
currency unions. There is no clear evidence, however, that the absolute values of these variables (neither in levels nor in growth rates) differ substantially across broken and sustained currency unions. While banking and exchange rate crises have been typically linked to rapid growth in credit and monetary aggregates, there is no measurable difference in the M2 to GDP ratio (or its growth rate), and also the interest rate spread (defined as the lending rate minus LIBOR) is no different (although this result may suffer from the small number of observations). The exceptions are the credit measures which show a pattern consistent with the theory; dissolved currency unions tend to involve countries with a particularly large domestic credit/GDP ratio (well above the ratio recorded for tranquil periods) so that the dissolution of the currency link may be the result of a boom (and bust cycle) in domestic lending.

For fiscal measures, I can only rarely reject the null of no difference in the behavior of these variables between countries that keep a currency union link and countries that depart from a common currency, but (again) many observations are missing. The only notable difference is in budget deficits; countries that leave a currency union tend to have less budgetary discipline.

Turning to openness indicators, there are at least three noteworthy observations. First, the behavior of current account balances does not vary substantially between broken and sustained currency unions ${ }^{11}$; if anything, the current account deficits are smaller before a break and there are smaller differences in pair-wise current account balances. Second, countries in dissolved currency unions tend to be less open (as measured by both the exportsto-GDP and the imports-to-GDP ratios), and they also experience a considerable decline in trade prior the break (as measured by both exports and imports growth). This decline in trade, however, is mostly confined to one of the currency union members; there is a large differential in trade growth across broken currency unions. There is also no significant decline in bilateral trade. Third, countries that exit a currency union receive on average smaller capital inflows (relative to GDP), but the difference to tranquil periods is not statistically significant.

Finally, a measure refers to the decolonization hypothesis that (in the past) currency union dissolutions mainly occurred when a colony gained independence and subsequently left the currency area of its former colonizer. As shown in the table, there is some evidence for the intuition. The mean of a dummy on a change in political status is larger for dissolved currency unions than for sustained ones and the difference is statistically highly significant. The

${ }^{11}$ Eichengreen et al. (1995) report similar findings for currency crises. 
average value of 0.05 , however, indicates that switches in political status preceded only about one-twentieth of the exchange rate regime transitions in the sample. ${ }^{12}$

\subsection{Multivariate Results}

The preceding comparisons are univariate. I now turn to multivariate analysis. More precisely, I estimate multinomial logit models (by maximum likelihood), linking a binary variable of currency union dissolution to a set of explanatory regressors. As noted above, I employ two measures of currency union exit: a binary variable which is defined as unity if the currency union link is dissolved in the following year (and zero otherwise), and a binary variable which is defined as unity if the link is broken in one of the next three years.

My exact empirical strategy is dictated by the limited availability of macroeconomic data which often reduces the number of usable observations. Combining the effects of the variables together into a single model would reduce sample size dramatically. Therefore, I apply a two-step procedure.

In a first step, I estimate a baseline regression that includes only a small set of potentially important explanatory variables. In particular, I use as standard regressors: GDP growth, inflation, bilateral trade growth and change in political union. This specification is not the result of extensive pre-testing. Rather, it ensures that, on the one hand, a broad range of potential explanations for the break-up of currency unions is covered, while, on the other hand, the cost of lost observations is minimized. In a later stage, I add the remaining variables to this fixed set of controls, one at a time. ${ }^{13}$

The benchmark results are reported in the first column of table 2. Results are tabulated for a currency union dissolution in the following year; results are similar for a break in the following three years. Since logit coefficients are not easily interpretable, I am particularly interested in the direction of the link. Associated $z$-statistics which test the null hypothesis of no effect are in brackets.

The estimates are not especially encouraging in the sense that there do not appear to be tight links between currency union dissolutions and their posited determinants. As shown, only one variable has a statistically significant coefficient, the pair-wise difference in inflation. The positive coefficient implies that a large difference in inflation performance

\footnotetext{
${ }^{12}$ Another promising approach would be to divide the sample of currency unions by the reasons for their initial adoption. One would expect that economic factors primarily explain the dissolution of voluntarily adopted currency unions, while political factors may be of overwhelming importance for the break-up of colonial and federal country currency unions. I am grateful to Charles Goodhart for pointing this out to me.
} 
Table 2: Baseline Results

\begin{tabular}{lccc}
\hline & $(1)$ & $(2)$ & $(3)$ \\
\cline { 2 - 4 } Real GDP Growth, minimum & -0.039 & $-0.027 \#$ & \\
Real GDP Growth, difference & $(-1.614)$ & $(-1.798)$ & \\
Inflation, maximum & 0.014 & 0.001 & \\
& $(0.807)$ & $(0.082)$ & \\
Inflation, difference & 0.014 & & 0.018 \\
& $(0.721)$ & & $(0.939)$ \\
Bilateral Trade Growth & $0.094^{* *}$ & & $0.074 * *$ \\
Change in Political Union, dummy & $(3.006)$ & & -0.001 \\
& -0.001 & -0.003 & $(-0.211)$ \\
& $(-0.137)$ & $(-0.838)$ & 0.455 \\
\# of observations & 0.404 & $0.993 \#$ & $(0.439)$ \\
McFadden R ${ }^{2}$ & $(0.384)$ & $(1.855)$ & 1548 \\
\hline
\end{tabular}

Notes: Multinomial logit estimation. z-statistics are in parentheses. Constant not reported. Explanatory variables refer to the year before the currency union dissolution. $* *, *$ and $\#$ denote significant at the $1 \%, 5 \%$ and $10 \%$ level, respectively. 
across currency union members is associated with a significant increase the likelihood of a currency union dissolution, holding all else constant. ${ }^{14}$ All the other variables have correctly signed, but insignificant coefficients, though some (like the minimum GDP growth rate) are close to significance. This somewhat weak result is not too surprising, however, given the large number of failed attempts to link exchange rates (in general) and currency crises (in particular) to macroeconomic fundamentals. Eichengreen et al. (1995, pp. 254-55), for instance, summarize their detailed analysis of causes and consequences of foreign exchange market turbulences by noting that "regime transitions such as exchange rate flotations ... are difficult to distinguish systematically from periods of tranquillity ... [so that] ... there do not appear to be clear early warning signals which precede changes in exchange rate regimes."

In the remaining columns of table 2 , I report the results of two alternative specifications. Dropping the inflation measures almost doubles the number of observations and (slightly) raises the statistical significance of the coefficients on real GDP growth and on a change in political union, but the coefficients remain insignificant on the conventional 5 percent level of confidence. The benchmark results are basically unaffected when measures of GDP growth are dropped.

Table 3 performs the extensions. In the upper half of the table, I report the results for the baseline variables. More specifically, I tabulate the range of the estimated coefficients, the maximum/minimum absolute value of the $z$-statistics and the number of times in which the coefficient enters a regression statistically significantly (at the 5 percent level).

Although the estimates vary substantially across specifications, the results are generally reassuring. As before, the inflation differential has the most precisely estimated impact on the likelihood of a currency union dissolution; a large difference in inflation performance is consistently strongly and significantly associated with the incidence of a currency union break. ${ }^{15}$ In some specifications, also other baseline variables have significant coefficients, most notably the dummy on a change in political union (which enters significantly in about one-fourth of the regressions). ${ }^{16}$ Thus, there is some evidence that a split in political union is often quickly followed by currency union dissolution.

In the lower half of the table, the results for the other (additionally entered) variables are shown. Broadly, the results from univariate analyses are confirmed. The coefficients on

\footnotetext{
${ }^{13}$ Grace Juhn and Paolo Mauro (2002) follow a similar approach.

${ }^{14}$ Barro (1996, pp. 65-68) argues that prior colonial status (by colonizer) may be an useful instrument for inflation.

${ }^{15}$ The inflation differential is the only baseline variable that does not change sign in any of the perturbations.
} 
per capita income take on the expected sign but just miss statistical significance. Similarly financial measures are often just little below conventional significance levels; only a large difference in the interest rate spread is significantly associated with a higher probability of a currency union, perhaps in anticipation of this event. Fiscal measures are, as before, mostly insignificant (including the budget deficit), while a small degree of openness (especially in one of the countries) and low trade growth both coincide with an increased probability of a currency union dissolution.

To summarize, with the possible exception of inflation differentials, there are only few clearly significant links between macroeconomic fundamentals and currency union dissolutions. ${ }^{17}$ On the positive side, trade openness appears to matter. Currency unions that include countries which trade only very little (as a share of GDP) are likely to dissolve, especially at a time when the countries experience a decline in external trade. ${ }^{18}$ Also changes in political status appear to be important; a break-up in political union is often accompanied by a break-up of the currency link. On the negative side, there is little evidence that the comovement of output and the symmetry of shocks has a measurable effect on the sustainability of a currency union. Similarly, fiscal aspects that play an important role in the design of the European Monetary Union (in the form of the stability and growth pact) have no predictive power for currency union dissolution.

\section{$\underline{\text { V. More Details }}$}

The previous results are derived from a large sample of very diverse experiences. For many economic variables, differences between broken and sustained currency unions are masked by large variances; economic conditions often vary considerably across currency union break-ups. ${ }^{19}$ In this section, I therefore present some more illustrative details of the data set.

\footnotetext{
${ }^{16}$ If significant, coefficients have the expected sign.

${ }^{17}$ I have performed extensive robustness checks. For instance, I have: used probit models; split the sample into pre- and post-1975; excluded politically motivated currency union breakups (i.e., when a colony gained independence); and distinguished between membership in bilateral and multilateral arrangements. In all of these cases, the estimates were basically identical with the baseline results. As expected, economic factors appear to be somewhat stronger for currency union dissolutions unrelated to political events, and multilateral arrangements seem to be more robust. There is also some evidence that the (pair-wise) minimum GDP growth rate might have an effect.

${ }^{18}$ Additionally controlling for country size has no measurable effect.

${ }^{19}$ This result basically confirms the findings of Benjamin Cohen (2001). After examining seven case studies, Cohen concludes (similar to Goodhart) that economic variables (or organizational characteristics) are only second order issues; the sustainability of currency
} 
Table 3: Extensions

\begin{tabular}{|c|c|c|c|c|c|c|}
\hline Baseline Variables & & $\begin{array}{l}\max . \\
\text { coeff. }\end{array}$ & $\begin{array}{l}\min . \\
\text { coeff. }\end{array}$ & $\begin{array}{l}\max . \\
|z|-\text { stat. }\end{array}$ & $\begin{array}{r}\min . \\
|z|-\text { stat. }\end{array}$ & $\begin{array}{c}\text { number } \\
\text { significant }\end{array}$ \\
\hline \multirow[t]{2}{*}{ Real GDP Growth } & minimum & 0.024 & -1.169 & 2.47 & 0.12 & 5 \\
\hline & difference & 0.103 & -0.229 & 2.62 & 0.01 & 2 \\
\hline \multirow[t]{2}{*}{ Inflation } & maximum & 0.423 & -0.049 & 2.31 & 0.03 & 3 \\
\hline & difference & 0.455 & 0.036 & 3.03 & 0.29 & 15 \\
\hline Bilateral Trade Growth & pair-wise & 0.015 & -0.061 & 1.01 & 0.03 & 0 \\
\hline Change in Political Union & dummy & 6.218 & -33.035 & 3.10 & 0.00 & 6 \\
\hline Additional Variables & & coeff. & Z-stat. & $\begin{array}{c}\text { McFadden } \\
\mathrm{R}^{2}\end{array}$ & $\begin{array}{c}\text { number } \\
\text { obs. }\end{array}$ & $\begin{array}{c}\text { number } \\
\text { cu breaks }\end{array}$ \\
\hline \multicolumn{7}{|l|}{ A. Macroeconomic Variables } \\
\hline \multirow[t]{2}{*}{ Real GDP per Capita } & minimum & -0.009 & -1.87 & 0.82 & 695 & 6 \\
\hline & difference & 0.002 & 1.86 & & & \\
\hline \multirow[t]{2}{*}{ Private Consumption Growth } & minimum & 0.003 & 0.07 & 0.11 & 1104 & 25 \\
\hline & difference & -0.053 & -1.81 & & & \\
\hline \multirow[t]{2}{*}{ Total Consumption Growth } & minimum & 0.041 & 0.86 & 0.20 & 941 & 15 \\
\hline & difference & -0.027 & -0.74 & & & \\
\hline \multicolumn{7}{|l|}{ B. Financial Variables } \\
\hline \multirow[t]{2}{*}{$\mathrm{M} 2 / \mathrm{GDP}$} & maximum & 0.040 & 1.68 & 0.20 & 1071 & 14 \\
\hline & difference & 0.038 & 1.22 & & & \\
\hline \multirow[t]{2}{*}{ M2/GDP Growth } & minimum & 0.060 & 1.53 & 0.09 & 972 & 9 \\
\hline & difference & -0.002 & -0.04 & & & \\
\hline \multirow[t]{2}{*}{ Interest Rate Spread } & maximum & -0.058 & -0.46 & 0.13 & 682 & 4 \\
\hline & difference & 0.440 & 2.30 & & & \\
\hline \multirow[t]{2}{*}{ Credit to Private Sector } & maximum & 0.002 & 0.09 & 0.13 & 1100 & 18 \\
\hline & difference & 0.041 & 1.66 & & & \\
\hline \multirow[t]{2}{*}{ Credit to Priv. Sector Growth } & minimum & 0.011 & 0.57 & 0.10 & 999 & 11 \\
\hline & difference & 0.013 & 1.83 & & & \\
\hline \multirow[t]{2}{*}{ Domestic Banking Credit } & maximum & 0.019 & 1.27 & 0.11 & 1099 & 18 \\
\hline & difference & 0.011 & 0.56 & & & \\
\hline \multirow[t]{2}{*}{ Dom. Banking Credit Growth } & minimum & 0.003 & 0.14 & 0.10 & 997 & 11 \\
\hline & difference & 0.014 & 2.25 & & & \\
\hline \multicolumn{7}{|l|}{ C. Fiscal Variables } \\
\hline \multirow[t]{2}{*}{ Current Revenue } & maximum & 0.097 & 1.08 & 0.14 & 265 & 4 \\
\hline & difference & -0.197 & -1.37 & & & \\
\hline \multirow[t]{2}{*}{ Tax Revenue } & maximum & 0.031 & 0.29 & 0.12 & 315 & 5 \\
\hline & difference & -0.044 & -0.33 & & & \\
\hline \multirow[t]{2}{*}{ Trade Taxes } & maximum & -0.246 & -2.42 & 0.29 & 303 & 7 \\
\hline & difference & 0.209 & 2.18 & & & \\
\hline \multirow[t]{2}{*}{ Expenditures } & maximum & 0.066 & 0.85 & 0.20 & 285 & 5 \\
\hline & difference & 0.035 & 0.47 & & & \\
\hline \multirow[t]{2}{*}{ Budget Deficit } & maximum & -0.100 & -0.43 & 0.20 & 261 & 5 \\
\hline & difference & 0.001 & 0.01 & & & \\
\hline \multirow[t]{2}{*}{ Central Government Debt } & maximum & -0.642 & -1.04 & 0.66 & 62 & 3 \\
\hline & difference & 0.871 & 0.98 & & & \\
\hline
\end{tabular}


Table 3 continued

Additional Variables

D. Openness Variables

\begin{tabular}{|c|c|c|c|c|c|c|}
\hline Current Account & minimum & 0.007 & 0.10 & 0.39 & 846 & 10 \\
\hline & difference & -0.226 & -1.93 & & & \\
\hline Exports/GDP & maximum & -0.041 & -2.13 & 0.10 & 1273 & 32 \\
\hline & difference & 0.025 & 1.17 & & & \\
\hline Export Growth & minimum & -0.037 & -1.70 & 0.18 & 953 & 14 \\
\hline & difference & -0.013 & -0.72 & & & \\
\hline Export Duties & maximum & 0.245 & 1.77 & 0.51 & 291 & 4 \\
\hline & difference & -0.070 & -0.50 & & & \\
\hline Imports/GDP & maximum & -0.078 & -3.66 & 0.14 & 1273 & 2 \\
\hline & difference & 0.083 & 3.84 & & & \\
\hline Import Growth & minimum & -0.065 & -2.16 & 0.23 & 953 & 4 \\
\hline & difference & 0.020 & 1.35 & & & \\
\hline Import Duties & maximum & -0.488 & -2.66 & 0.36 & 279 & f \\
\hline & difference & 0.373 & 2.11 & & & \\
\hline Trade/GDP & maximum & -0.017 & -0.19 & 0.59 & 677 & 6 \\
\hline & difference & -0.148 & -1.31 & & & \\
\hline Gross FDI & maximum & -0.548 & -0.28 & 0.51 & 612 & 6 \\
\hline & difference & 0.490 & 0.24 & & & \\
\hline Gross Private Capital Flows & maximum & 0.156 & 0.68 & 0.65 & 616 & \\
\hline & difference & -0.887 & -1.69 & & & \\
\hline
\end{tabular}

Notes: Multinomial logit estimation. The six baseline variables (and an unreported constant) are included in all regressions. Additional variables are (pair-wise) entered as seventh/eigth regressor; coefficients significant at the 5\% level are in bold. For the baseline variables the minimum and maximum absolute values of the $\mathrm{z}$ statistic in any of the regressions are reported, and the number of cases in which the variable is significant at the $5 \%$ level. Explanatory variables refer to the year before the currency union dissolution. 
A large fraction of the currency unions in the sample are country pairs in which a dependent territory uses the currency of the colonizing country; these currency union links were often dissolved after the colonies gained independence. However, while many of these countries established a national central bank immediately after (or even before) independence, the date when the peg was given up varies markedly. Figure 2 plots a histogram of the time period between political independence and currency union exit. Excluding transitive cases, the sample comprises 69 currency union dissolutions. Of these 69 exits, four involve still existing dependencies (Bermuda, Djibouti, Reunion, St. Pierre et Miquelon); another five links were dissolved before the territory gained independence (The Bahamas, Brunei Darussalam, Qatar, Vanuatu, Zimbabwe). The remaining 60 cases spread over time, with about two-thirds of the exits (37 cases) occurring within ten years after political independence. Examples for longlasting currency unions between sovereign nations include the link of the Irish pound to the British pound and the peg of the Malagasy franc to the French franc. ${ }^{20}$

Figures 3 and 4 present some case study evidence for economic measures for which I find significant differences between broken and sustained currency unions. Figure 3 focuses on the inflation differential; the figure provides 8 time-series plots of the difference in national inflation rates before (and immediately after) currency union dissolution (an event marked with a vertical line). As the graphs clearly show, broken currency unions tend to display considerable differences in consumer price inflation before exit, often sizably above the average for sustained currency unions (marked with a horizontal line). Further, it is mainly the country that leaves the union that experiences high inflation, often caused by severe fiscal imbalances.

Figure 4 provides analogues for differences in import growth. Illustrating previous regression results, large differences in import growth often preceded currency union dissolutions, with especially the departing country experiencing a sometimes dramatic decline in trade.

unions primarily depends on the "political will". However, while giving up a currency union is ultimately a political decision (as is the decision to establish or join a monetary union), my regression results show that economic issues are not completely irrelevant.

${ }^{20}$ Ireland departed from its sterling link in 1979, 58 years after independence from the United Kingdom. Madagascar was a member of the French franc zone from independence in 1960 until 1973. After withdrawal in 1973, the Malagasy franc remained pegged to the French franc for another nine years until April 2, 1982. 
Figure 2: Currency Union Dissolutions and Political Independence

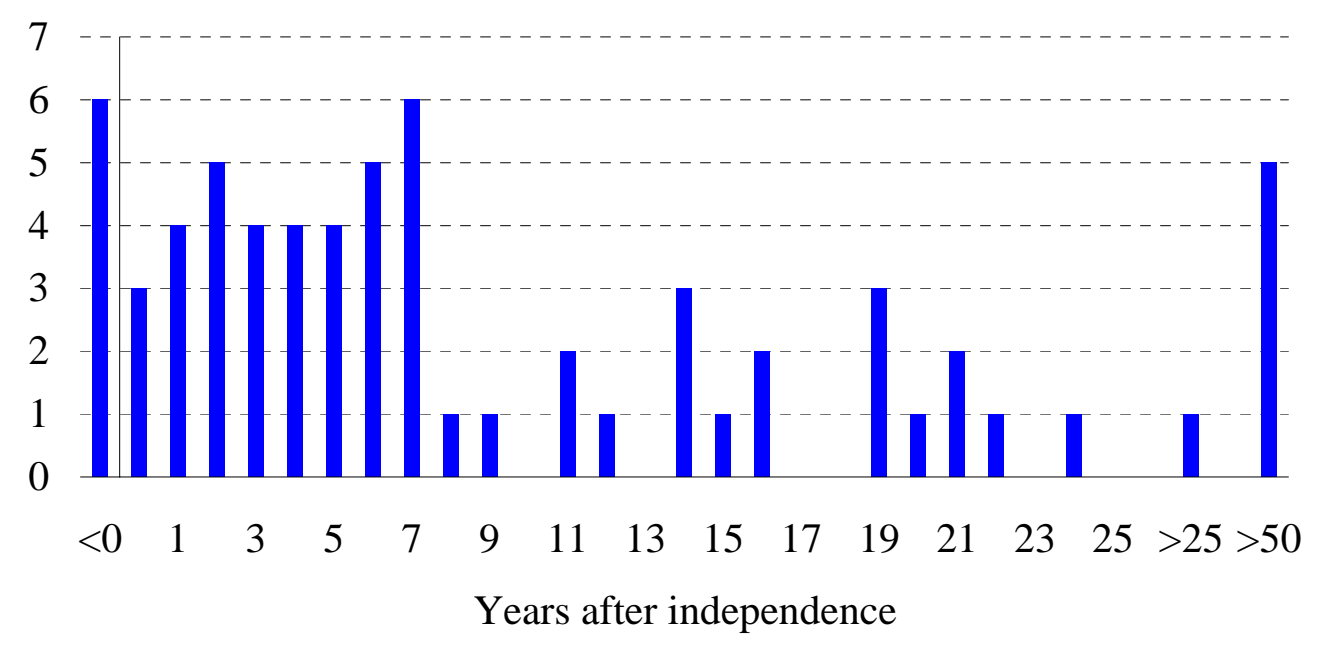

Notes: The columns give the number of switches out of a currency union for the year after political independence. The total sample comprises 69 currency union dissolutions; four of these exits involve still dependent territories. 
Figure 3: Inflation Differentials - Selected Country Pairs

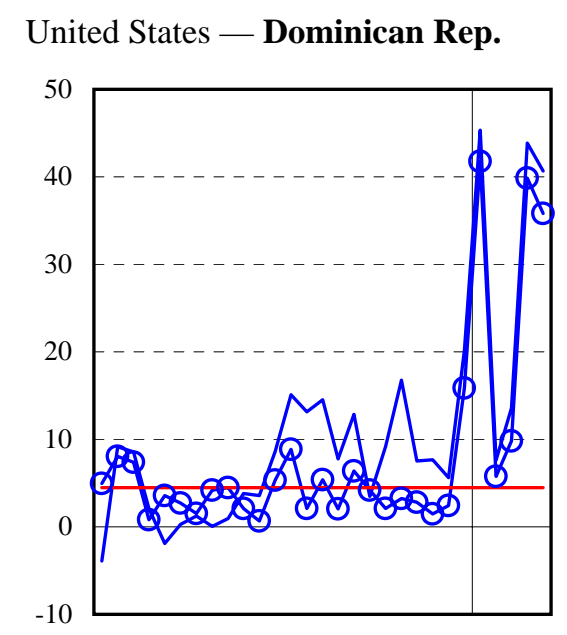

$1961 \quad 1966 \quad 1971 \quad 1976 \quad 1981 \quad 1986$

\section{Netherlands Antilles — Suriname}

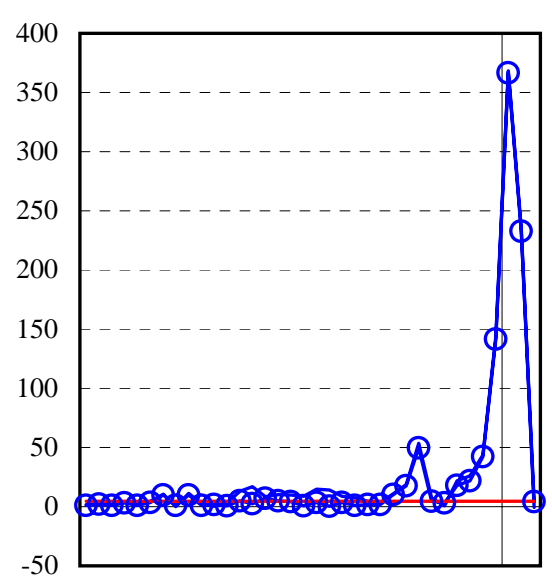

$\begin{array}{llllll}1961 & 1967 & 1973 & 1979 & 1985 & 1991\end{array}$

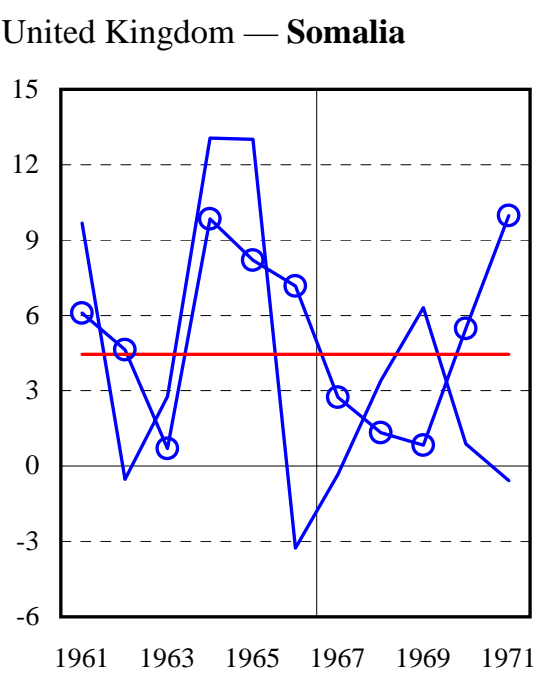

Burma (Myanmar) — Pakistan

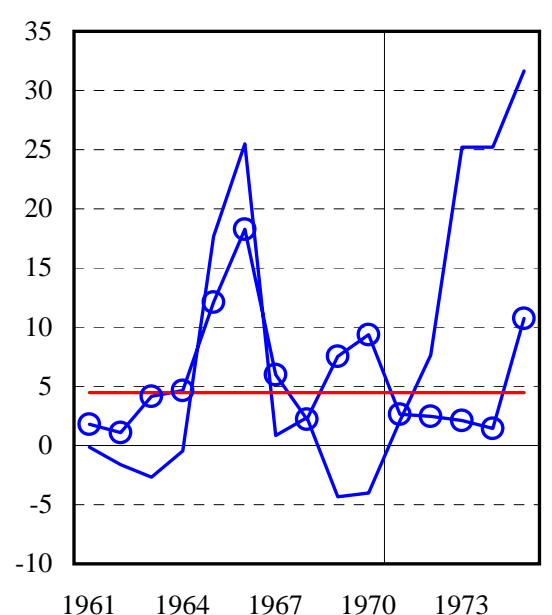

Australia — Tonga

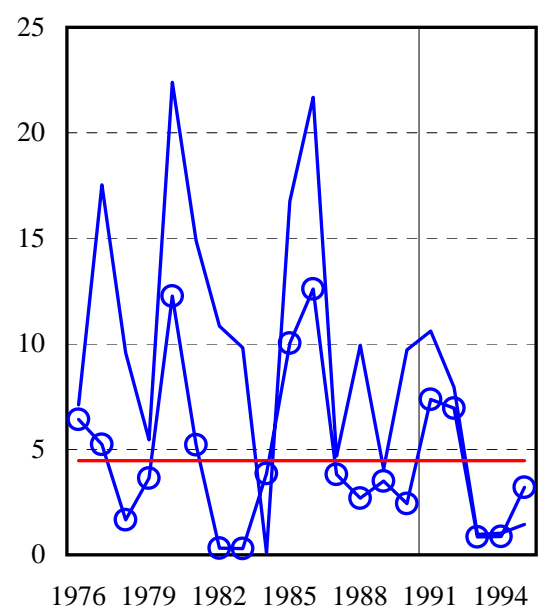

Sri Lanka — India

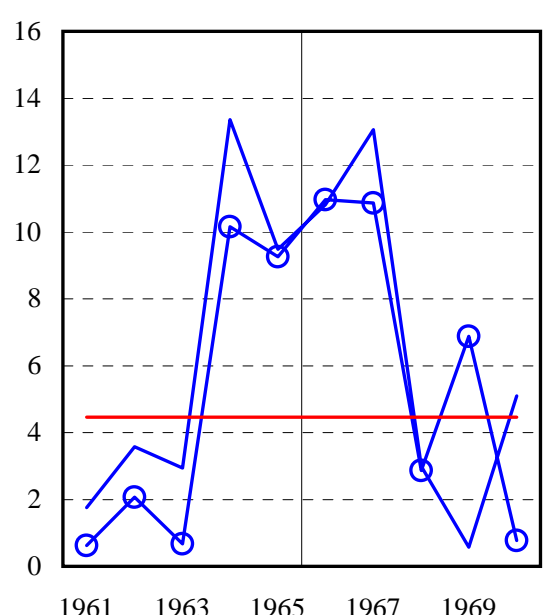

Barbados — Trinidad \& Tobago

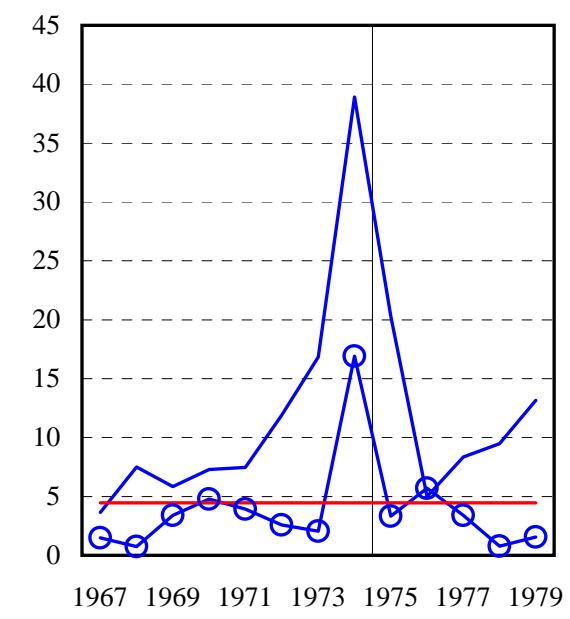

Cameroon - Madagascar

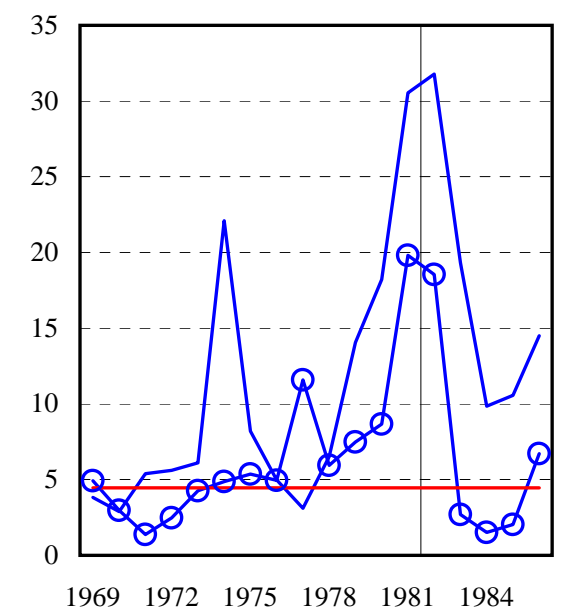

Notes: The graphs show the inflation differential for selected country pairs (circled line), the average inflation differential for sustained currency unions (horizontal line), and inflation rates for the country that leaves the currency union (indicated in bold). The date of currency union exit is marked with the vertical line. 
Figure 4: Import Growth Differentials - Selected Country Pairs
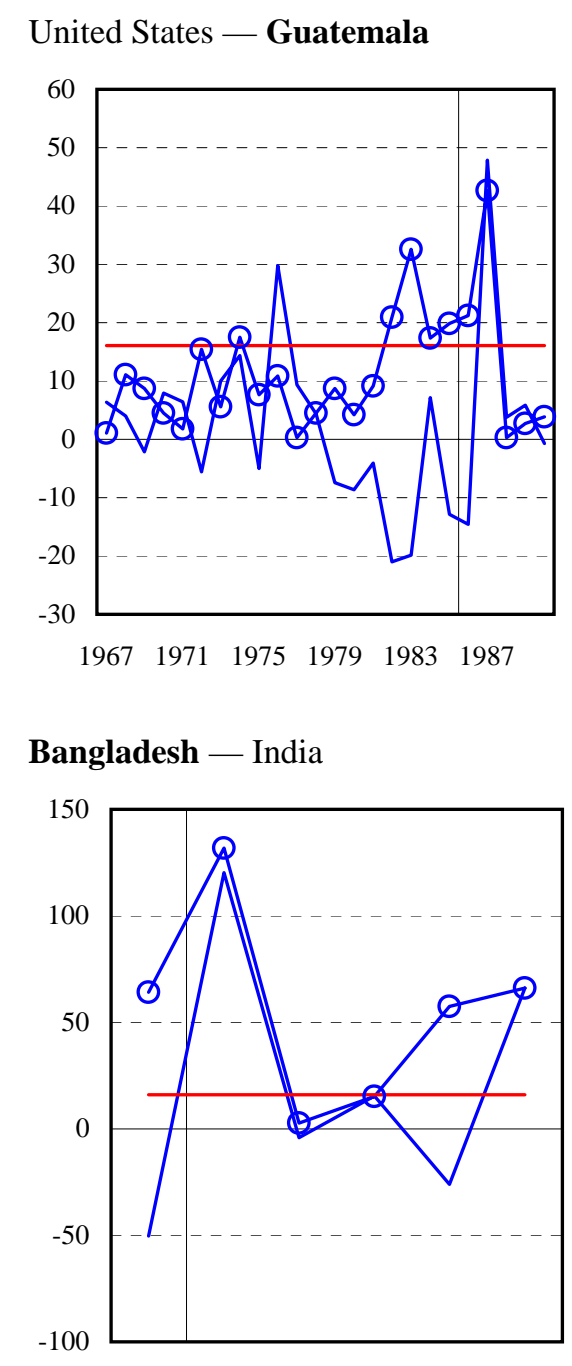

$19731974197519761977 \quad 1978$
United Kingdom — Gambia

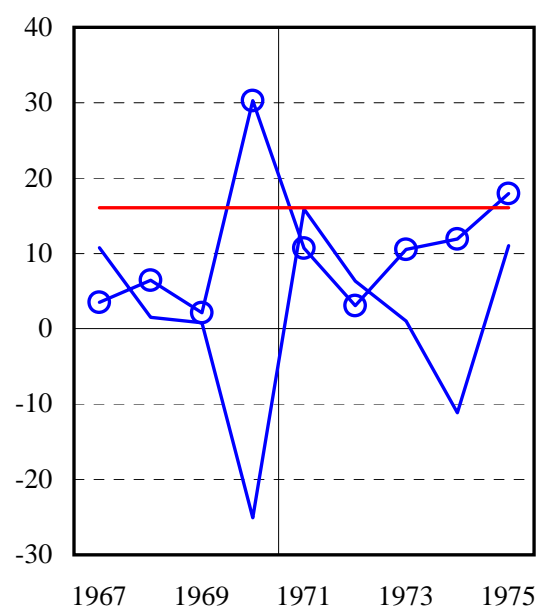

Burma (Myanmar) — Pakistan

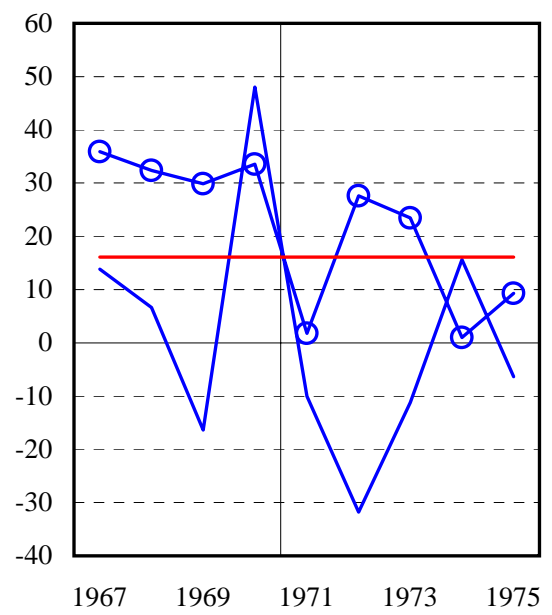

Portugal — Guinea-Bissau

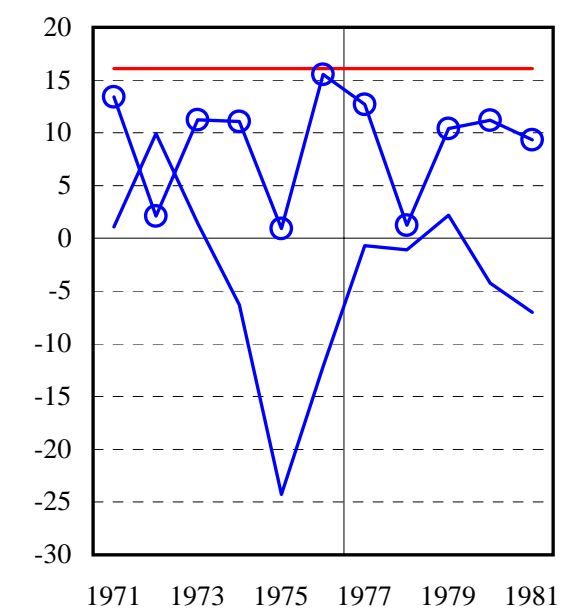

Congo, Rep. of - Mauritania

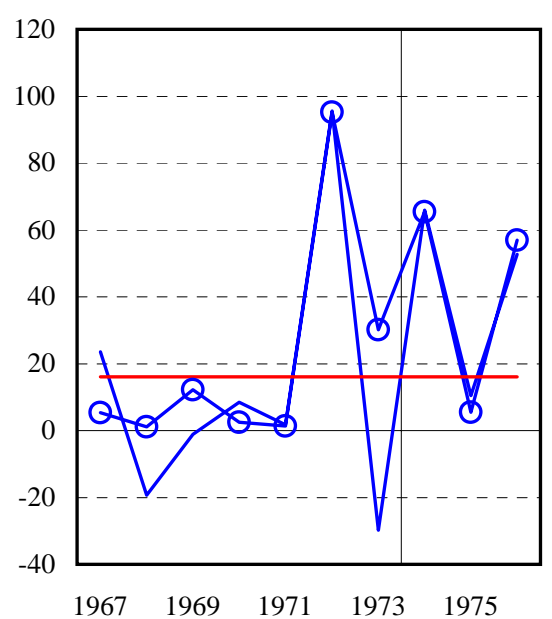

Guyana - Trinidad \& Tobago

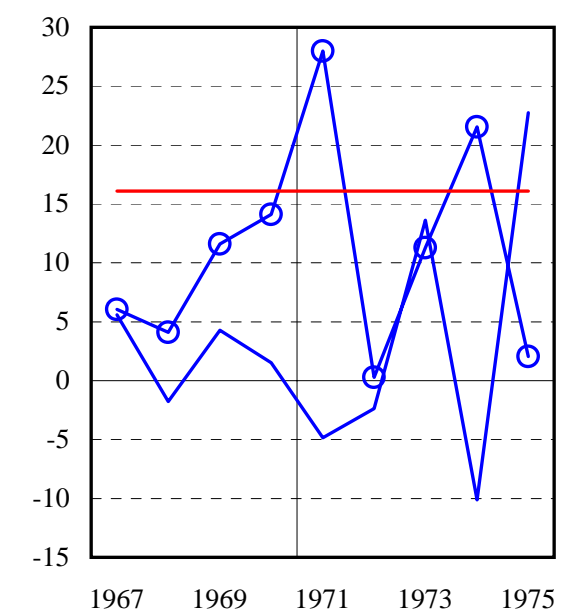

Cote d'Ivoire - Madagascar

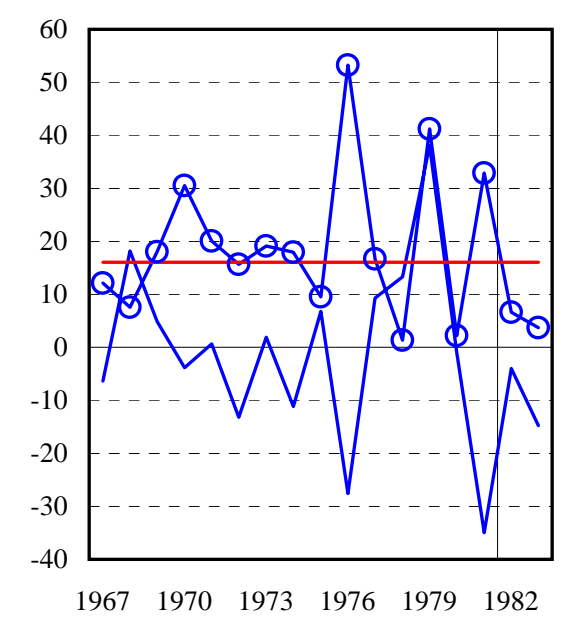

Notes: The graphs show the import growth differential for selected country pairs (circled line), the average import growth differential for sustained currency unions (horizontal line), and import growth for the country that leaves the currency union (indicated in bold). The date of currency union exit is marked with the vertical line. 


\section{$\underline{\text { VI. Conclusions }}$}

A growing number of countries actively considers to abandon its national currency and to enter a monetary union. The motives for the adoption of a foreign currency (which implies the loss of some national independence and sovereignty) range from the desire for closer economic integration to the introduction of external discipline.

Since sharing a common currency involves not only benefits but also comes with some costs, much of the literature on currency unions focuses on the pros and cons of monetary integration; many empirical studies discuss this trade-off in the context of proposed monetary unions.

In this paper, I follow another route. In particular, I search for stylized facts associated with the break-up of currency unions; a characterization of currency union exits allows to answer the question of when does a common currency link become unsustainable. I examine annual data for 245 country pairs that share the same money from 1948 through 1997.

I find that a large inflation differential between currency union members is consistently associated with a high likelihood of a currency union dissolution; an obvious extension would be to search for potential causes of this divergence in inflation performance. Many departures from a currency union link also occurred when a political union is dissolved. Somewhat surprisingly, neither asymmetries in output nor fiscal variables matter for a typical break of a currency union.

\section{References:}

Alesina, Alberto and Robert J. Barro. 2001. "Dollarization,” American Economic Review. 91 (May): 381-385.

Alesina, Alberto and Robert J. Barro. 2002. “Currency Unions,” Quarterly Journal of Economics. 67 (May): 409-436.

Alesina, Alberto, Robert J. Barro and Silvana Tenreyro. 2002. "Optimal Currency Areas," in Macroeconomics Annual: 2002. (forthcoming) 
Barro, Robert J. 1996. "Determinants of Economic Growth: A Cross-Country Empirical Study,” NBER Working Paper \#5698. Cambridge, MA: National Bureau of Economic Research (August).

Bomberger, William A. 2002. "Decolonization and Estimates of the Time Series Effect of Currency Unions," University of Florida.

Chang, Roberto and Andrés Velasco. 2002. "Dollarization: Analytical Issues,” NBER Working Paper \#8838. Cambridge, MA: National Bureau of Economic Research (March).

Cohen, Benjamin J. 2001. "Beyond EMU: The Problem of Sustainability," in Barry J. Eichengreen and Jeffry A. Frieden (eds.) The Political Economy of European Monetary Unification (second edition). Boulder: Westview Press.

Eichengreen, Barry, Andrew K. Rose and Charles Wyplosz. 1995. "Exchange Market Mayhem: The Antecedents and Aftermath of Speculative Attacks," Economic Policy. 21 (October): 251-312.

Frankel, Jeffrey A. and Andrew K. Rose. 1996. "Currency Crashes in Emerging Markes: An Empirical Treatment," Journal of International Economics. 41 (November): 351-366.

Glick, Reuven and Andrew K. Rose. 2002. "Does a Currency Union Affect Trade? The TimeSeries Evidence,” European Economic Review. 46 (June): 1125-1151.

Goodhart, Charles A. E. 1995. “The Political Economy of Monetary Union,” in Peter B. Kenen (ed.) Understanding Independence. Princeton: Princeton University Press.

Juhn, Grace and Paolo Mauro. 2002. "Long-Run Determinants of Exchange Rate Regimes: A Simple Sensitivity Analysis,” IMF Working Paper 02/104. Washington: International Monetary Fund (June).

Kaminsky, Graciela L., Saul Lizondo and Carmen M. Reinhart. 1998. "Leading Indicators of Currency Crises,” IMF Staff Papers. 45 (March): 1-48. 
Kaminsky, Graciela L. and Carmen M. Reinhart. 1999. "The Twin Crises: The Causes of Banking and Balance-of-Payments Problems," American Economic Review. 89 (June): 473500.

Mundell, Robert A. 1961. "A Theory of Optimum Currency Areas," American Economic Review. 51 (September): 657-665.

Rose, Andrew K. and Charles Engel. 2002. "Currency Unions and International Integration," Journal of Money, Credit, and Banking. 34 (August): 804-826. 


\section{Appendix: Currency Unions in Sample}

\begin{tabular}{|c|c|c|c|c|c|c|c|c|c|}
\hline$\# \mathrm{cu}$ & break & \multicolumn{2}{|c|}{ Currency Union Members } & \multirow{2}{*}{$\begin{array}{l}\text { End } \\
\text { ongoing }\end{array}$} & \multirow{2}{*}{$\begin{array}{r}\# \mathrm{cu} \\
56\end{array}$} & \multirow{2}{*}{ break } & \multirow{2}{*}{\multicolumn{2}{|c|}{$\begin{array}{l}\text { Currency Union Members } \\
\text { Central African Repu Cote d'Ivoire }\end{array}$}} & \multirow{2}{*}{$\begin{array}{l}\text { End } \\
\text { ongoing }\end{array}$} \\
\hline 1 & & Antigua \& Barbuda & Dominica & & & & & & \\
\hline 2 & & Antigua \& Barbuda & Grenada & ongoing & 57 & & Central African Re & Equatorial Guinea & ongoing \\
\hline 3 & & Antigua \& Barbuda & St. Vincent \& the Grt & fongoing & 58 & & Central African Re & Gabon & ongoing \\
\hline 4 & & Aruba & Netherlands Antilles & ongoing & 59 & 21 & Central African Re & Madagascar & 1982 \\
\hline 5 & & Australia & Kiribati & ongoing & 60 & & Central African Re & u Mali & ongoing \\
\hline 6 & & Australia & Nauru & ongoing & 61 & & Central African Re & u Niger & ongoing \\
\hline 7 & 1 & Australia & Solomon Islands & 1979 & 62 & & Central African Re & Senegal & ongoing \\
\hline 8 & 2 & Australia & Tonga & 1991 & 63 & & Central African Re & Togo & ongoing \\
\hline 9 & & Australia & Tuvalu & ongoing & 64 & & Chad & Benin & ongoing \\
\hline 10 & 3 & Bangladesh & India & 1974 & 65 & & Chad & Burkina Faso & ongoing \\
\hline 11 & 4 & Barbados & Grenada & 1975 & 66 & & Chad & Congo, Rep. of & ongoing \\
\hline 12 & 5 & Barbados & Guyana & 1971 & 67 & & Chad & Cote d'Ivoire & ongoing \\
\hline 13 & 6 & Barbados & Trinidad \& Tobago & 1975 & 68 & & Chad & Gabon & ongoing \\
\hline 14 & 7 & Belgium-Luxembour & Congo, Dem. Rep. of & 1961 & 69 & 22 & Chad & Madagascar & 1982 \\
\hline 15 & 8 & Belgium-Luxembour & Rwanda & 1966 & 70 & & Chad & Niger & ongoing \\
\hline 16 & & Benin & Burkina Faso & ongoing & 71 & & Chad & Senegal & ongoing \\
\hline 17 & & Benin & Cote d'Ivoire & ongoing & 72 & & Chad & Togo & ongoing \\
\hline 18 & & Benin & Equatorial Guinea & ongoing & 73 & 23 & Comoros & Burkina Faso & 1994 \\
\hline 19 & & Benin & Gabon & ongoing & 74 & 24 & Comoros & Cote d'Ivoire & 1994 \\
\hline 20 & 9 & Benin & Guinea & 1969 & 75 & 25 & Comoros & Madagascar & 1982 \\
\hline 21 & & Benin & Guinea-Bissau & ongoing & 76 & 26 & Comoros & Niger & 1994 \\
\hline 22 & 10 & Benin & Madagascar & 1982 & 77 & 27 & Comoros & Reunion & 1976 \\
\hline 23 & & Benin & Mali & ongoing & 78 & 28 & Comoros & Senegal & 1994 \\
\hline 24 & 11 & Benin & Mauritania & 1974 & 79 & & Congo, Rep. of & Benin & ongoing \\
\hline 25 & & Benin & Niger & ongoing & 80 & & Congo, Rep. of & Burkina Faso & ongoing \\
\hline 26 & 12 & Benin & Reunion & 1976 & 81 & & Congo, Rep. of & Cote d'Ivoire & ongoing \\
\hline 27 & & Benin & Senegal & ongoing & 82 & & Congo, Rep. of & Gabon & ongoing \\
\hline 28 & & Benin & Togo & ongoing & 83 & 29 & Congo, Rep. of & Madagascar & 1982 \\
\hline 29 & & Bhutan & India & ongoing & 84 & & Congo, Rep. of & Mali & ongoing \\
\hline 30 & 13 & Brunei Darussalam & Malaysia & 1971 & 85 & 30 & Congo, Rep. of & Mauritania & 1974 \\
\hline 31 & & Brunei Darussalam & Singapore & ongoing & 86 & & Congo, Rep. of & Niger & ongoing \\
\hline 32 & 14 & Burma (Myanmar) & India & 1966 & 87 & 31 & Congo, Rep. of & Reunion & 1976 \\
\hline 33 & 15 & Burma (Myanmar) & Pakistan & 1971 & 88 & & Congo, Rep. of & Senegal & ongoing \\
\hline 34 & & Cameroon & Benin & ongoing & 89 & & Congo, Rep. of & Togo & ongoing \\
\hline 35 & & Cameroon & Burkina Faso & ongoing & 90 & & Cote d'Ivoire & Burkina Faso & ongoing \\
\hline 36 & & Cameroon & Central African Repu & ongoing & 91 & 32 & Cote d'Ivoire & Madagascar & 1982 \\
\hline 37 & & Cameroon & Chad & ongoing & 92 & 33 & Cote d'Ivoire & Mali & 1962/ong \\
\hline 38 & 16 & Cameroon & Comoros & 1994 & 93 & 34 & Cote d'Ivoire & Mauritania & 1974 \\
\hline 39 & & Cameroon & Congo, Rep. of & ongoing & 94 & & Cote d'Ivoire & Niger & ongoing \\
\hline 40 & & Cameroon & Cote d'Ivoire & ongoing & 95 & 35 & Cote d'Ivoire & Reunion & 1976 \\
\hline 41 & & Cameroon & Equatorial Guinea & ongoing & 96 & & Cote d'Ivoire & Senegal & ongoing \\
\hline 42 & & Cameroon & Gabon & ongoing & 97 & & Cote d'Ivoire & Togo & ongoing \\
\hline 43 & 17 & Cameroon & Guinea & 1969 & 98 & & Denmark & Faeroe Islands & ongoing \\
\hline 44 & & Cameroon & Guinea-Bissau & ongoing & 99 & & Denmark & Greenland & ongoing \\
\hline 45 & 18 & Cameroon & Madagascar & 1982 & 100 & 36 & Djibouti & Madagascar & 1949 \\
\hline 46 & & Cameroon & Mali & ongoing & 101 & & Dominica & Grenada & ongoing \\
\hline 47 & 19 & Cameroon & Mauritania & 1974 & 102 & & Dominica & Montserrat & ongoing \\
\hline 48 & & Cameroon & Niger & ongoing & 103 & & Dominica & St. Kitts \& Nevis & ongoing \\
\hline 49 & & Cameroon & Senegal & ongoing & 104 & & Dominica & St. Lucia & ongoing \\
\hline 50 & & Cameroon & Togo & ongoing & 105 & & Dominica & St. Vincent \& the $C$ & rf ongoing \\
\hline 51 & & Central African Rep & u Benin & ongoing & 106 & & Equatorial Guinea & Burkina Faso & ongoing \\
\hline 52 & & Central African Rep & u Burkina Faso & ongoing & 107 & & Equatorial Guinea & Cote d'Ivoire & ongoing \\
\hline 53 & & Central African Rep & u Chad & ongoing & 108 & & Equatorial Guinea & Mali & ongoing \\
\hline 54 & 20 & Central African Rep & u Comoros & 1994 & 109 & & Equatorial Guinea & Senegal & ongoing \\
\hline 55 & & Central African Repu & u Congo, Rep. of & ongoing & 110 & & Equatorial Guinea & Togo & ongoing \\
\hline
\end{tabular}




\begin{tabular}{|c|c|c|}
\hline 111 & 37 & France \\
\hline 112 & & France \\
\hline 113 & & France \\
\hline 114 & & France \\
\hline 115 & 38 & France \\
\hline 116 & & France \\
\hline 117 & & France \\
\hline 118 & 39 & France \\
\hline 119 & & Gabon \\
\hline 120 & & Gabon \\
\hline 121 & 40 & Gabon \\
\hline 122 & 41 & Gabon \\
\hline 123 & & Gabon \\
\hline 124 & 42 & Gabon \\
\hline 125 & & Gabon \\
\hline 126 & 43 & Gabon \\
\hline 127 & & Gabon \\
\hline 128 & & Gabon \\
\hline 129 & 44 & Gambia \\
\hline 130 & 45 & Gambia \\
\hline 131 & 46 & Gambia \\
\hline 132 & 47 & Ghana \\
\hline 133 & 48 & Ghana \\
\hline 134 & 49 & Grenada \\
\hline 135 & & Grenada \\
\hline 136 & & Grenada \\
\hline 137 & & Grenada \\
\hline 138 & & Grenada \\
\hline 139 & 50 & Grenada \\
\hline 140 & 51 & Guinea \\
\hline 141 & 52 & Guinea \\
\hline 142 & 53 & Guinea \\
\hline 143 & 54 & Guinea \\
\hline 144 & & Guinea-Bissau \\
\hline 145 & & Guinea-Bissau \\
\hline 146 & & Guinea-Bissau \\
\hline 147 & & Guinea-Bissau \\
\hline 148 & 55 & India \\
\hline 149 & 56 & India \\
\hline 150 & 57 & Kenya \\
\hline 151 & 58 & Kenya \\
\hline 152 & 59 & Kenya \\
\hline 153 & 60 & Kuwait \\
\hline 154 & 61 & Madagascar \\
\hline 155 & 62 & Madagascar \\
\hline 156 & 63 & Madagascar \\
\hline 157 & 64 & Madagascar \\
\hline 158 & 65 & Madagascar \\
\hline 159 & 66 & Madagascar \\
\hline 160 & 67 & Malawi \\
\hline 161 & 68 & Malawi \\
\hline 162 & 69 & Malaysia \\
\hline 163 & 70 & Maldives \\
\hline 164 & & Mali \\
\hline 165 & & Mali \\
\hline
\end{tabular}

\begin{tabular}{|c|c|}
\hline Algeria & 1969 \\
\hline French Guiana & ongoing \\
\hline Guadeloupe & ongoing \\
\hline Martinique & ongoing \\
\hline Morocco & 1959 \\
\hline Reunion & ongoing \\
\hline \multicolumn{2}{|c|}{ St. Pierre \& Miquelol ongoing } \\
\hline Tunisia & 1958 \\
\hline Burkina Faso & ongoing \\
\hline Cote d'Ivoire & ongoing \\
\hline Guinea & 1969 \\
\hline Madagascar & 1982 \\
\hline Mali & ongoing \\
\hline Mauritania & 1974 \\
\hline Niger & ongoing \\
\hline Reunion & 1976 \\
\hline Senegal & ongoing \\
\hline Togo & ongoing \\
\hline Ghana & 1965 \\
\hline Nigeria & 1967 \\
\hline Sierra Leone & 1965 \\
\hline Nigeria & 1965 \\
\hline Sierra Leone & 1965 \\
\hline Guyana & 1971 \\
\hline Montserrat & ongoing \\
\hline St. Kitts \& Nevis & ongoing \\
\hline St. Lucia & ongoing \\
\hline \multicolumn{2}{|c|}{ St. Vincent \& the Grs ongoing } \\
\hline Trinidad \& Tobago & 1976 \\
\hline Cote d'Ivoire & 1969 \\
\hline Mali & 1962 \\
\hline Mauritania & 1969 \\
\hline Senegal & 1969 \\
\hline Burkina Faso & ongoing \\
\hline Cote d'Ivoire & ongoing \\
\hline Senegal & ongoing \\
\hline Togo & ongoing \\
\hline Mauritius & 1966 \\
\hline Pakistan & 1966 \\
\hline Somalia & 1971 \\
\hline Tanzania & 1978 \\
\hline Uganda & 1978 \\
\hline India & 1961 \\
\hline Burkina Faso & 1982 \\
\hline Mauritania & 1974 \\
\hline Niger & 1982 \\
\hline Reunion & 1976 \\
\hline Senegal & 1982 \\
\hline Togo & 1982 \\
\hline Zambia & 1967 \\
\hline Zimbabwe & 1967 \\
\hline Singapore & 1971 \\
\hline Pakistan & 1971 \\
\hline Burkina Faso & ongoing \\
\hline Niger & ongoing \\
\hline
\end{tabular}

\begin{tabular}{|c|c|c|c|c|}
\hline 166 & & Mali & Senegal & ongoing \\
\hline 167 & & Mali & Togo & ongoing \\
\hline 168 & 71 & Mauritania & Niger & 1974 \\
\hline 169 & 72 & Mauritania & Senegal & 1974 \\
\hline 170 & 73 & Mauritania & Togo & 1974 \\
\hline 171 & 74 & Mauritius & Seychelles & 1976 \\
\hline 172 & & Montserrat & \multicolumn{2}{|c|}{ St. Vincent \& the Grt ongoing } \\
\hline 173 & 75 & Netherlands Antilles & Suriname & 1994 \\
\hline 174 & & New Caledonia & French Polynesia & ongoing \\
\hline 175 & 76 & New Caledonia & Vanuatu & 1971 \\
\hline 176 & & New Caledonia & Wallis \& Futuna & ongoing \\
\hline 177 & 77 & New Zealand & Samoa & 1967 \\
\hline 178 & & Niger & Burkina Faso & ongoing \\
\hline 179 & & Niger & Senegal & ongoing \\
\hline 180 & & Niger & Togo & ongoing \\
\hline 181 & 78 & Nigeria & Sierra Leone & 1965 \\
\hline 182 & 79 & Oman & India & 1970 \\
\hline 183 & 80 & Pakistan & Mauritius & 1967 \\
\hline 184 & 81 & Portugal & Angola & 1976 \\
\hline 185 & 82 & Portugal & Cape Verde & 1977 \\
\hline 186 & 83 & Portugal & Guinea-Bissau & 1977 \\
\hline 187 & 84 & Portugal & Mozambique & 1977 \\
\hline 188 & 85 & Portugal & Sao Tome \& Principє & 1977 \\
\hline 189 & 86 & Qatar & India & 1966 \\
\hline 190 & & Qatar & \multicolumn{2}{|c|}{ United Arab Emirate: ongoing } \\
\hline 191 & 87 & Reunion & Burkina Faso & 1976 \\
\hline 192 & 88 & Reunion & Senegal & 1976 \\
\hline 193 & & Senegal & Burkina Faso & ongoing \\
\hline 194 & & Senegal & Togo & ongoing \\
\hline 195 & 89 & Somalia & Tanzania & 1971 \\
\hline 196 & 90 & Somalia & Uganda & 1971 \\
\hline 197 & 91 & Sri Lanka & India & 1966 \\
\hline 198 & 92 & Sri Lanka & Pakistan & 1967 \\
\hline 199 & & St. Kitts \& Nevis & \multicolumn{2}{|c|}{ St. Vincent \& the Gro ongoing } \\
\hline 200 & 93 & \multicolumn{2}{|c|}{ St. Pierre \& Miquelol Cote d'Ivoire } & 1976 \\
\hline 201 & 94 & \multicolumn{2}{|c|}{ St. Pierre \& Miquelol Gabon } & 1976 \\
\hline 202 & 95 & \multicolumn{2}{|c|}{ St. Pierre \& Miquelo Reunion } & 1976 \\
\hline 203 & 96 & \multicolumn{2}{|c|}{ St. Pierre \& Miquelo! Togo } & 1976 \\
\hline 204 & & St. Lucia & \multicolumn{2}{|c|}{ St. Vincent \& the Gro ongoing } \\
\hline 205 & 97 & Tanzania & Uganda & 1978 \\
\hline 206 & & Togo & Burkina Faso & ongoing \\
\hline 207 & 98 & United Kingdom & Bahamas & 1966 \\
\hline 208 & 99 & United Kingdom & Bermuda & 1970 \\
\hline 209 & 100 & United Kingdom & Cyprus & 1972 \\
\hline 210 & & United Kingdom & Falkland Islands & ongoing \\
\hline 211 & 101 & United Kingdom & Gambia & 1971 \\
\hline 212 & 102 & United Kingdom & Ghana & 1965 \\
\hline 213 & & United Kingdom & Gibraltar & ongoing \\
\hline 214 & 103 & United Kingdom & Iraq & 1967 \\
\hline 215 & 104 & United Kingdom & Ireland & 1979 \\
\hline 216 & 105 & United Kingdom & Israel & 1954 \\
\hline 217 & 106 & United Kingdom & Jamaica & 1969 \\
\hline 218 & 107 & United Kingdom & Jordan & 1967 \\
\hline 219 & 108 & United Kingdom & Kenya & 1967 \\
\hline 220 & 109 & United Kingdom & Kuwait & 1967 \\
\hline
\end{tabular}




$\begin{array}{lrllr}221 & 110 & \text { United Kingdom } & \text { Libya } & 1967 \\ 222 & 111 & \text { United Kingdom } & \text { Malawi } & 1971 \\ 223 & 112 & \text { United Kingdom } & \text { Malta } & 1971 \\ 224 & 113 & \text { United Kingdom } & \text { New Zealand } & 1967 \\ 225 & 114 & \text { United Kingdom } & \text { Nigeria } & 1967 \\ 226 & 115 & \text { United Kingdom } & \text { Oman } & 1971 \\ 227 & 116 & \text { United Kingdom } & \text { Samoa } & 1967 \\ 228 & 117 & \text { United Kingdom } & \text { Sierra Leone } & 1965 \\ 229 & 118 & \text { United Kingdom } & \text { Somalia } & 1967 \\ 230 & 119 & \text { United Kingdom } & \text { South Africa } & 1961 \\ 231 & & \text { United Kingdom } & \text { St. Helena } & \text { ongoing } \\ 232 & 120 & \text { United Kingdom } & \text { Tanzania } & 1967 \\ 233 & 121 & \text { United Kingdom } & \text { Uganda } & 1967 \\ 234 & 122 & \text { United Kingdom } & \text { Yemen } & 1972 \\ 235 & 123 & \text { United Kingdom } & \text { Zambia } & 1967 \\ 236 & 124 & \text { United Kingdom } & \text { Zimbabwe } & 1967 \\ 237 & & \text { United States } & \text { Bahamas } & \text { ongoing } \\ 238 & & \text { United States } & \text { Bermuda } & \text { ongoing } \\ 239 & 125 & \text { United States } & \text { Dominican Republic } & 1985 \\ 240 & & \text { United States } & \text { Guam } & \text { ongoing } \\ 241 & 126 & \text { United States } & \text { Guatemala } & 1986 \\ 242 & & \text { United States } & \text { Liberia } & \text { ongoing } \\ 243 & & \text { United States } & \text { Panama } & \text { ongoing } \\ 244 & 127 & \text { Vanuatu } & \text { French Polynesia } & 1971 \\ 245 & 128 & \text { Zimbabwe } & \text { Zambia } & 1967\end{array}$




\section{CESifo Working Paper Series}

(for full list see www.cesifo.de)

1047 Volker Grossmann, Firm Size and Diversification: Asymmetric Multiproduct Firms under Cournot Competition, September 2003

1048 Dan Anderberg, Insiders, Outsiders, and the Underground Economy, October 2003

1049 Jose Apesteguia, Steffen Huck and Jörg Oechssler, Imitation - Theory and Experimental Evidence, October 2003

1050 G. Abío, G. Mahieu and C. Patxot, On the Optimality of PAYG Pension Systems in an Endogenous Fertility Setting, October 2003

1051 Carlos Fonseca Marinheiro, Output Smoothing in EMU and OECD: Can We Forego Government Contribution? A Risk Sharing Approach, October 2003

1052 Olivier Bargain and Nicolas Moreau, Is the Collective Model of Labor Supply Useful for Tax Policy Analysis? A Simulation Exercise, October 2003

1053 Michael Artis, Is there a European Business Cycle?, October 2003

1054 Martin R. West and Ludger Wößmann, Which School Systems Sort Weaker Students into Smaller Classes? International Evidence, October 2003

1055 Annette Alstadsaeter, Income Tax, Consumption Value of Education, and the Choice of Educational Type, October 2003

1056 Ansgar Belke and Ralph Setzer, Exchange Rate Volatility and Employment Growth: Empirical Evidence from the CEE Economies, October 2003

1057 Carsten Hefeker, Structural Reforms and the Enlargement of Monetary Union, October 2003

1058 Henning Bohn and Charles Stuart, Voting and Nonlinear Taxes in a Stylized Representative Democracy, October 2003

1059 Philippe Choné, David le Blanc and Isabelle Robert-Bobée, Female Labor Supply and Child Care in France, October 2003

1060 V. Anton Muscatelli, Patrizio Tirelli and Carmine Trecroci, Fiscal and Monetary Policy Interactions: Empirical Evidence and Optimal Policy Using a Structural New Keynesian Model, October 2003

1061 Helmuth Cremer and Pierre Pestieau, Wealth Transfer Taxation: A Survey, October 2003 
1062 Henning Bohn, Will Social Security and Medicare Remain Viable as the U.S. Population is Aging? An Update, October 2003

1063 James M. Malcomson, Health Service Gatekeepers, October 2003

1064 Jakob von Weizsäcker, The Hayek Pension: An efficient minimum pension to complement the welfare state, October 2003

1065 Joerg Baten, Creating Firms for a New Century: Determinants of Firm Creation around 1900 , October 2003

1066 Christian Keuschnigg, Public Policy and Venture Capital Backed Innovation, October 2003

1067 Thomas von Ungern-Sternberg, State Intervention on the Market for Natural Damage Insurance in Europe, October 2003

1068 Mark V. Pauly, Time, Risk, Precommitment, and Adverse Selection in Competitive Insurance Markets, October 2003

1069 Wolfgang Ochel, Decentralising Wage Bargaining in Germany - A Way to Increase Employment?, November 2003

1070 Jay Pil Choi, Patent Pools and Cross-Licensing in the Shadow of Patent Litigation, November 2003

1071 Martin Peitz and Patrick Waelbroeck, Piracy of Digital Products: A Critical Review of the Economics Literature, November 2003

1072 George Economides, Jim Malley, Apostolis Philippopoulos, and Ulrich Woitek, Electoral Uncertainty, Fiscal Policies \& Growth: Theory and Evidence from Germany, the UK and the US, November 2003

1073 Robert S. Chirinko and Julie Ann Elston, Finance, Control, and Profitability: The Influence of German Banks, November 2003

1074 Wolfgang Eggert and Martin Kolmar, The Taxation of Financial Capital under Asymmetric Information and the Tax-Competition Paradox, November 2003

1075 Amihai Glazer, Vesa Kanniainen, and Panu Poutvaara, Income Taxes, Property Values, and Migration, November 2003

1076 Jonas Agell, Why are Small Firms Different? Managers' Views, November 2003

1077 Rafael Lalive, Social Interactions in Unemployment, November 2003

1078 Jean Pisani-Ferry, The Surprising French Employment Performance: What Lessons?, November 2003

1079 Josef Falkinger, Attention, Economies, November 2003 
1080 Andreas Haufler and Michael Pflüger, Market Structure and the Taxation of International Trade, November 2003

1081 Jonas Agell and Helge Bennmarker, Endogenous Wage Rigidity, November 2003

1082 Fwu-Ranq Chang, On the Elasticities of Harvesting Rules, November 2003

1083 Lars P. Feld and Gebhard Kirchgässner, The Role of Direct Democracy in the European Union, November 2003

1084 Helge Berger, Jakob de Haan and Robert Inklaar, Restructuring the ECB, November 2003

1085 Lorenzo Forni and Raffaela Giordano, Employment in the Public Sector, November 2003

1086 Ann-Sofie Kolm and Birthe Larsen, Wages, Unemployment, and the Underground Economy, November 2003

1087 Lars P. Feld, Gebhard Kirchgässner, and Christoph A. Schaltegger, Decentralized Taxation and the Size of Government: Evidence from Swiss State and Local Governments, November 2003

1088 Arno Riedl and Frans van Winden, Input Versus Output Taxation in an Experimental International Economy, November 2003

1089 Nikolas Müller-Plantenberg, Japan’s Imbalance of Payments, November 2003

1090 Jan K. Brueckner, Transport Subsidies, System Choice, and Urban Sprawl, November 2003

1091 Herwig Immervoll and Cathal O'Donoghue, Employment Transitions in 13 European Countries. Levels, Distributions and Determining Factors of Net Replacement Rates, November 2003

1092 Nabil I. Al-Najjar, Luca Anderlini \& Leonardo Felli, Undescribable Events, November 2003

1093 Jakob de Haan, Helge Berger and David-Jan Jansen, The End of the Stability and Growth Pact?, December 2003

1094 Christian Keuschnigg and Soren Bo Nielsen, Taxes and Venture Capital Support, December 2003

1095 Josse Delfgaauw and Robert Dur, From Public Monopsony to Competitive Market. More Efficiency but Higher Prices, December 2003

1096 Clemens Fuest and Thomas Hemmelgarn, Corporate Tax Policy, Foreign Firm Ownership and Thin Capitalization, December 2003

1097 Laszlo Goerke, Tax Progressivity and Tax Evasion, December 2003 
1098 Luis H. B. Braido, Insurance and Incentives in Sharecropping, December 2003

1099 Josse Delfgaauw and Robert Dur, Signaling and Screening of Workers' Motivation, December 2003

1100 Ilko Naaborg,, Bert Scholtens, Jakob de Haan, Hanneke Bol and Ralph de Haas, How Important are Foreign Banks in the Financial Development of European Transition Countries?, December 2003

1101 Lawrence M. Kahn, Sports League Expansion and Economic Efficiency: Monopoly Can Enhance Consumer Welfare, December 2003

1102 Laszlo Goerke and Wolfgang Eggert, Fiscal Policy, Economic Integration and Unemployment, December 2003

1103 Nzinga Broussard, Ralph Chami and Gregory D. Hess, (Why) Do Self-Employed Parents Have More Children?, December 2003

1104 Christian Schultz, Information, Polarization and Delegation in Democracy, December 2003

1105 Daniel Haile, Abdolkarim Sadrieh and Harrie A. A. Verbon, Self-Serving Dictators and Economic Growth, December 2003

1106 Panu Poutvaara and Tuomas Takalo, Candidate Quality, December 2003

1107 Peter Friedrich, Joanna Gwiazda and Chang Woon Nam, Development of Local Public Finance in Europe, December 2003

1108 Silke Uebelmesser, Harmonisation of Old-Age Security Within the European Union, December 2003

1109 Stephen Nickell, Employment and Taxes, December 2003

1110 Stephan Sauer and Jan-Egbert Sturm, Using Taylor Rules to Understand ECB Monetary Policy, December 2003

1111 Sascha O. Becker and Mathias Hoffmann, Intra-and International Risk-Sharing in the Short Run and the Long Run, December 2003

1112 George W. Evans and Seppo Honkapohja, The E-Correspondence Principle, January 2004

1113 Volker Nitsch, Have a Break, Have a ... National Currency: When Do Monetary Unions Fall Apart?, January 2004 